\title{
GEOGRAPHY AND ECONOMIC DEVELOPMENT
}

\section{JOHN LUKE GALLUP}

Center for International Development, Harvard University, Cambridge, MA, john_gallup@harvard.edu

\section{JEFFREY D. SACHS}

Center for International Development, Harvard University, Cambridge, MA, jeffrey_sachs@harvard.edu

\section{ANDREW D. MELLINGER}

Center for International Development, Harvard University, Cambridge, MA, andrew_mellinger@harvard.edu

\begin{abstract}
Location and climate have large effects on income levels and income growth through their effects on transport costs, disease burdens, and agricultural productivity, among other channels. Geography also seems to affect economic policy choices. Many geographic regions that have not been conducive to modern economic growth have high population densities and are experiencing rapid increases in population. At particular disadvantage are regions located far from coasts and ocean-navigable rivers, for which the transport costs of international trade are high, and tropical regions, which bear a heavy burden of disease. Moreover, a large portion of population growth over the next thirty years is expected to occur in these geographically disadvantaged regions.
\end{abstract}

Two centuries after the start of modern economic growth, much of the world's population remains mired in poverty. Some benefits of modern development, especially gains in life expectancy and drops in infant mortality, have spread to nearly all parts of the world (although huge discrepancies remain). But in material wellbeing - as measured by gross domestic product (GDP) per capita adjusted for purchasing power parity (PPP) - the yawning gaps show few signs of narrowing. In 1820, average GDP per capita in Western Europe was about three times that in Africa; by 1992, it was more than thirteen times as high. More stunning, GDP per capita in Africa in 1992 was \$1,284 (measured in 1990 PPP-adjusted dollars) - the same as in Western Europe in 1820 (Maddison 1995). Asia has experienced significant income growth over the past thirty years, with average incomes rising from $\$ 1,212$ in 1965 to \$3,239 in 1992. ${ }^{1}$ But in Africa, incomes were identical in 1971 
and 1992, and in Latin America and the Caribbean, average income grew just 7 percent between 1974 and 1992.

\section{THE RELATIONSHIP BETWEEN GEOGRAPHY AND ECONOMIC DEVELOPMENT}

Examination of a global map of GDP per capita reveals two striking relationships between geography and economic development (see Map 1). First, nearly all countries in the geographic tropics are poor, and almost all countries in the mid- and high latitudes are rich. ${ }^{2}$ Second, coastal countries generally have higher incomes than do landlocked countries. Indeed, none of the twenty-nine landlocked countries outside of Europe enjoys a high per capita income.

The distribution of population density, measured as people per square kilometer, also reveals important information (see Map 2). ${ }^{3}$ First, there is no simple relationship between population density and income level. ${ }^{4}$ Some densely populated areas are rich (Western Europe), whereas others are poor (China, India, Indonesia). Some sparsely populated areas are rich (Australia, New Zealand), whereas others are poor (the Sahel of Africa). Across countries, there is only a weak positive correlation between population density and GDP per capita. Second, the Eurasian landmass is more densely populated than the rest of the world. (This seems to be a function of human history in addition to underlying geophysical and biogeographical conditions, as we show below.) Third, coastlines and areas connected to the coast by navigable rivers are more densely populated than hinterlands (regions more than 100 kilometers from the coast or a navigable river leading to the ocean).

To elucidate some of the causes of population density, and the subtle relationship between population density and income, we calculate GDP density-GDP per capita times population density-measured as GDP per square kilometer (see Map 3). In line with Maps 1 and 2, the coastal, temperate countries of the Northern Hemisphere have the world's highest GDP densities. Four of these areas-Western Europe, northeast Asia (coastal China, Japan, and the Republic of Korea), and the eastern and western seaboards of the United States and Canada-are the core economic zones of the modern world. ${ }^{5}$ These regions are the overwhelming providers of capital goods in global trade, contain the world's financial centers, and generate a large portion of global production.

The parts of the United States, Western Europe, and northeast Asia that lie within 100 kilometers of the coast contain just 3 percent of the world's inhabited land area and 13 percent of its population, yet they account for at least 32 percent of global GDP (measured in PPP terms). ${ }^{6}$ Excluding coastal China, the core coastal regions contain a mere 9 percent of the world's population but produce at least 30 percent of global GDP. Eleven economies in North America, Western Europe, and East Asia contain 14 percent of the world's population yet are responsible for 88 
percent of global exports of capital goods (machinery and transport equipment) (World Trade Organization [WTO] 1995). ${ }^{7}$

To take a closer look at these patterns, we examine GDP per capita in the 150 countries with populations of greater than 1 million in 1995. Together, these countries contained 5.65 billion people in 1995, 99.7 percent of the global total. For purposes of discussion, we define a tropical country as one where at least half of the land area falls within the geographic tropics. About 41 percent of the world's population lives in the seventy-two tropical countries; 59 percent lives in the seventyeight nontropical countries. Among the tropical countries, the simple (unweighted by country population) average GDP per capita in 1995 was $\$ 3,326$; among the nontropical countries, it was $\$ 9,027$. A simple test of the difference of means across the two groups is significant at the $p<.001$ level.

It is convenient to divide the nontropical countries into two groups, temperatezone and subtropical. In subtropical countries, at least half the land area is made up of tropical or subtropical ecological zones but more than half of the land area is outside the geographic tropics. ${ }^{8}$ There are fifteen subtropical countries, with a mean income of $\$ 7,874$, and sixty-three temperate-zone countries, with a mean income of $\$ 9,302$. If we consider only the countries that were not socialist after World War II, the geographic divide is even sharper: average per capita income is $\$ 3,685$ in nonsocialist tropical, $\$ 9,248$ in nonsocialist subtropical, and $\$ 14,828$ in nonsocialist temperate-zone countries.

Only two of the thirty richest economies (ranked by 1995 PPP-adjusted GDP per capita) are tropical, and both are tiny: Hong Kong (China) and Singapore. Of the twenty-seven others, four are subtropical and twenty-three are temperate. The two tropical economies account for just 1.0 percent of the combined population of the thirty richest economies. Adjusting for the fact that part of the population in four of the thirty richest economies-Australia, Chile, Taiwan (China), and the United Arab Emirates-lives in tropical regions increases the tropical share of population in the thirty richest economies to 2.3 percent.

As noted, nearly all of the world's landlocked countries are poor; the exceptions in Western and Central Europe are closely integrated with the regional European market and able to trade at low cost. ${ }^{9}$ Of the twenty-nine non-European landlocked countries with populations greater than 1 million, the richest is Botswana (thirtyeighth place), which owes it pride of place to well-managed diamond mines. The second richest is Belarus (sixty-eighth place). Income differences between landlocked and coastal countries outside Western and Central Europe are striking: the landlocked countries have an average income of $\$ 1,771$, whereas the coastal countries have an average income of $\$ 5,567(p=.001)$. The difference in economic density is even greater because landlocked countries tend to be sparsely populated (59 people per square kilometer compared with 207 people per square kilometer in coastal countries).

Of course, geography is not everything. Even geographically favored countries such as the temperate-zone, coastal Democratic People's Republic of Korea, and 
the well-situated Czechoslovakia failed to thrive under socialism. Still, development seems to favor temperate-zone countries-especially the twenty-three nonsocialist, Northern Hemisphere countries that have not been ravaged by war, where average per capita income is $\$ 18,000$. Using a multiple regression estimate for the seventy-eight nontropical countries, we find that being located in the Southern Hemisphere reduces average per capita income by $\$ 3,590$, being located in the subtropics reduces income by $\$ 4,785$, being landlocked reduces income by $\$ 5,190$, and being socialist reduces income by $\$ 10,053$.

To reveal some of the geographic factors associated with development, we identified major geographic characteristics for selected regions (see Table 1). ${ }^{10}$ This analysis reveals that sub-Saharan Africa, the poorest region, has several characteristics associated with low income: a high concentration of land in the tropics; a population concentrated in the interior (only 19 percent of Africans live within 100 kilometers of the coast), with more than a quarter living in landlocked countries (the highest of any region); lack of proximity to core markets in Europe; and low population densities in coastal and interior regions. By contrast, Western Europe, the richest region, is nontropical; its population is heavily concentrated near coastal areas, with almost no population in landlocked areas; and population density is moderate. In South Asia and the transition economies of Eastern Europe and the former Soviet Union, the population is concentrated in the interior rather than the coast. India's great mass of population, for example, lives in the Gangetic Valley, often hundreds of kilometers from the coast. South Asia is partly tropical and densely populated-indeed, it is the most densely populated region in the world-whereas the transition economies are nontropical and in the least densely populated region. Latin America is highly tropical and has low population densities and a moderately coastal population. The United States (not included in Table 1) has two enormous advantages for development: a large portion of population near the coast (38 percent of Americans live within 100 kilometers of the coast, or 67 percent if river systems leading to the ocean are included) and a temperate-zone landmass.

These patterns prompt several questions. How much has geography mattered for economic growth, once economic policies and institutions are controlled for? If geography mattered in the past, how much does it still matter today? Are there persistent advantages to early developers through agglomeration effects, learning by doing, and the like, or do latecomers have the advantage of the possibility of rapid growth through technological diffusion, capital imports, and other forces of convergence?

We believe that geography-along with economic and political institutions - continues to matter for economic development. Thus, geographic considerations should be taken into account in econometric and theoretical studies of cross-country economic growth, which have almost completely neglected geographic themes. ${ }^{11}$ Our broad conclusions, described below, can be summarized as follows: 
TABLE 1. Characteristics of Selected Regions

\begin{tabular}{|c|c|c|c|c|c|c|c|c|c|c|}
\hline Region & $\begin{array}{c}\text { GDP } \\
\text { per Capita } \\
\text { (U.S. } \\
\text { dollars) }\end{array}$ & $\begin{array}{l}\text { Population } \\
\text { (millions) }\end{array}$ & $\begin{array}{c}\text { Land Area } \\
\text { (millions } \\
\text { of square } \\
\mathrm{km} \text { ) }\end{array}$ & $\begin{array}{c}\text { Land in } \\
\text { Tropics } \\
\text { (\%) }\end{array}$ & $\begin{array}{c}\text { Population } \\
\text { within } \\
100 \mathrm{Km} \\
\text { of Coast } \\
(\%)\end{array}$ & $\begin{array}{l}\text { Population } \\
\text { within } \\
100 \mathrm{Km} \\
\text { of Coast or } \\
\text { Ocean- } \\
\text { Navigable } \\
\text { River } \\
(\%)\end{array}$ & $\begin{array}{l}\text { Landlocked } \\
\text { Population } \\
\quad(\%)\end{array}$ & $\begin{array}{c}\text { Distance } \\
\text { to core } \\
\text { market } \\
(\mathrm{km})\end{array}$ & $\begin{array}{c}\text { Coastal } \\
\text { Density } \\
\text { (population } \\
\text { per square } \\
\text { km) }\end{array}$ & $\begin{array}{c}\text { Interior } \\
\text { Density } \\
\text { (population } \\
\text { per square } \\
\mathrm{km} \text { ) }\end{array}$ \\
\hline Sub-Saharan Africa & 1,865 & 580 & 24 & 91 & 19 & 21 & 28 & 6,237 & 40 & 22 \\
\hline Western Europe & 19,230 & 383 & 3 & 0 & 53 & 89 & 4 & 922 & 109 & 125 \\
\hline East Asia & 10,655 & 1,819 & 14 & 30 & 43 & 60 & 0 & 3,396 & 381 & 91 \\
\hline South Asia & 1,471 & 1,219 & 4 & 40 & 23 & 41 & 2 & 5,744 & 387 & 287 \\
\hline Transition economies & 3,902 & 400 & 24 & 0 & 9 & 55 & 21 & 2,439 & 32 & 16 \\
\hline $\begin{array}{l}\text { Latin America and } \\
\text { the Caribbean }\end{array}$ & 5,163 & 472 & 20 & 73 & 42 & 45 & 3 & 4,651 & 52 & 18 \\
\hline
\end{tabular}

Source: See appendix.

Note: $\mathrm{GDP}=$ gross domestic product. Transition economies = Eastern Europe and the former Soviet Union 
- Relative to temperate regions, tropical regions are hindered in development by higher disease burdens and limitations on agricultural productivity.

- Relative to hinterlands, coastal regions and regions linked to coasts by oceannavigable waterways are strongly favored in development.

- Landlocked countries may be particularly disadvantaged by their lack of access to the sea, even when they are no farther than the interior parts of coastal countries, because cross-border migration of labor is more difficult than internal migration, infrastructure development across borders is much harder to arrange than similar investments within a country, and coastal countries may have military or economic incentives to impose costs on landlocked countries.

- High population density seems to be favorable for economic development in coastal regions with good access to internal, regional, and international trade. This may reflect increasing returns to scale in infrastructure networks or the enhanced division of labor in settings with high population densities. In hinterlands, by contrast, high population density appears to undermine development.

- Recent population growth is strongly negatively correlated with a country's potential for economic growth. That is, populations are growing fastest in countries that are least likely to experience rapid economic growth. More generally, there is no strong historical relationship between population growth and a region's potential for modern economic growth because population densities seem to have been driven more by agricultural productivity than by conditions for modern industry and services.

It is worth mentioning the relationship between our approach and the recent creative and important work on economic geography by Paul Krugman, Anthony J. Venables, and others (see elsewhere in this issue). The new economic geography follows the new trade theory by showing how increasing returns to scale, agglomeration economies, transport costs, and product differentiation can lead to a highly differentiated spatial organization of economic activity (including cities, hubs and spokes, international division of labor between industry and agriculture, and so on), even when the underlying physical geography is undifferentiated. New economic geography models illustrate the possibility of self-organizing spatial patterns of production based on agglomeration effects rather than on differences in climate, transport costs, or ecology.

Our starting point, by contrast, is that physical geography is highly differentiated and that these differences have a large effect on economic development. The two approaches can, of course, be complementary: a city might emerge because of cost advantages arising from differentiated geography but continue to thrive because of agglomeration economies even when the cost advantages have disappeared. Empirical work should aim to disentangle the forces of differential geography and self-organizing agglomeration economies. 


\section{GEOGRAPHY AND MODELS OF ECONOMIC GROWTH}

Although econometric studies of cross-country performance have neglected geography over the past decade, economists have long noted the crucial role of geographic factors. Indeed, Adam Smith (1976) gave considerable attention to the geographic correlates of growth. ${ }^{12}$ Smith saw geography as a crucial complement to economic institutions in determining the division of labor. His logic started with the notion that productivity depends on specialization and that specialization depends on the extent of the market. The extent of the market in turn depends on the freedom of markets and the costs of transport. And geography is crucial in transport costs:

As by means of water-carriage a more extensive market is opened to every sort of industry than what land-carriage alone can afford it, so it is upon sea-coast, and along the banks of navigable rivers, that industry of every kind naturally begins to subdivide and improve itself, and it is frequently not till a long time after that those improvements extend themselves to the inland part of the country. (Smith 1976, 25)

Given the crucial role of transport costs, Smith (1976) notes that

all the inland parts of Africa, and that part of Asia which lies any considerable way north of the Euxine [Black] and Caspian seas, the ancient Sycthia, the modern Tartary and Siberia, seem in all ages of the world to have been in the same barbarous and uncivilized state in which we find them at present. The sea of Tartary is the frozen ocean which admits of no navigation, and though some of the greatest rivers in the world run through that country, they are at too great a distance from one another to carry commerce and communication through the greater part of it. There are in Africa none of those great inlets, such as the Baltic and Adriatic seas in Europe, the Mediterranean and Euxine seas in both Europe and Asia, and the gulphs of Arabia, Persia, India, Bengal, and Siam, in Asia, to carry maritime commerce into the interior parts of that great continent. (P. 25)

Great thinkers such as Fernand Braudel (1972, 1981-1984) and William McNeill $(1963,1974)$ and important historians such as E. L. Jones (1981) and Alfred Crosby (1986) have placed geography and climate at the center of their explanations for Europe's preeminent success in economic development. Braudel points to the key role of Mediterranean and North Atlantic coastal countries as the creative centers of global capitalism after the fifteenth century. McNeill similarly stresses Europe's great advantages in coastal trade, navigable rivers, temperate climate, and disease patterns as fundamental conditions for its takeoff and eventual domination of the Americas and Australia. Crosby details the advantages of the temperate zones in climate, disease ecology, and agricultural productivity. Two important essays, one by Douglas Lee (1957) and one by Andrew Kamarck (1976), synthesize these arguments in excellent surveys on tropical development-surveys that have been largely ignored by the formal modelers of economic growth. 
One of the most interesting recent attempts to ground very long-term development in geographic and ecological considerations comes from ecologist Jared Diamond (1997), who asks why Eurasians (and people of Eurasian origin in the Americas and Australia) "dominate the modern world in wealth and development" (p. 15). He disposes of racial explanations not just on moral grounds but also on rigorous findings of the shared genetic inheritance of all human societies. His explanation rests instead on the long-term advantages of Eurasia in agglomeration economies and diffusion of technologies. Populations in the Americas and Australia were cut off by oceans from the vast majority of populations in Eurasia and Africa. Thus, they could not share, through trade and diffusion, in technological advances in agriculture, communications, transport, and the like.

Diamond (1997) also argues that because plant species and domesticated animals appropriate to one ecological zone may be inappropriate elsewhere, technological diffusion works most effectively within ecological zones and therefore in an east-west direction along a common latitude rather than in a north-south direction. Eurasia, he claims, enjoyed the benefit of its vast east-west axis heavily situated in temperate ecological zones, whereas Africa was disadvantaged by its north-south axis, which cuts across the Mediterranean climate in the north, the Saharan Desert, the equatorial tropics, and the southernmost subtropical regions. Diamond argues that these advantages, in addition to more contingent (i.e., accidental) advantages in indigenous plant and animal species, gave Eurasia a fundamental long-term advantage over the rest of the world.

Historians also have stressed the changing nature of geographic advantage as technology changes. In early civilizations, when transport and communications were too costly to support much interregional and international trade (and any oceanic trade), geographic advantage came from agricultural productivity rather than from access to markets. As a result, early civilizations almost invariably emerged in highly fertile river valleys such as those around the Nile, Indus, Tigris, Euphrates, Yellow, and Yangtze Rivers. These civilizations produced high-density populations that in later eras were disadvantaged by their remoteness from international trade. Northern Europe could not be densely settled before the discoveries of appropriate technologies and tools to fell its great forests (Landes 1998).

Similarly, as the advantages of overland and coastal-based trade between Europe and Asia gave way to oceanic commerce in the sixteenth century, economic advantage shifted from the Middle East and eastern Mediterranean to the North Atlantic. In the nineteenth century, the high costs of transporting coal for steam power meant that industrialization almost invariably depended on proximity to coal fields. This advantage disappeared with the discovery of petroleum refining, the production of oil- and hydro-based electricity, and the reduced cost of bulk transport. Railroads, automobiles, air transport, and telecommunications have reduced the advantages of coastlines relative to hinterlands, but according to the evidence below, the advantages of sea-based trade remain. 


\section{FORMAL MODELS OF GEOGRAPHY AND DEVELOPMENT}

To establish some formal ideas about the interaction between geography and development, we start with the simplest model of economic growth, the AK model (known in its earlier incarnation as the Harrod-Domar model), and add transport costs. In the resulting model, growth differences across countries depend on several parameters that we find to be important in later empirical analysis. These factors include underlying total factor productivity, denoted by $A$, which may differ across countries because of fundamental geographic reasons (such as differences in productivity between temperate and tropical agriculture and differences in endemic health conditions among ecozones); transport costs, reflecting both distances and physical access to trade (navigability of rivers, distance from the coast); and national saving rates and, implicitly, government economic policies.

Suppose that an economy has the aggregate production function

$$
Q=A K \text {. }
$$

The capital stock $(K)$ evolves according to

$$
\frac{\mathrm{d} K}{\mathrm{~d} t}=I-\delta K
$$

where $I$ is investment and $\delta$ is the rate of depreciation.

We assume for the moment that population is constant and normalized to 1 , so that $Q$ represents both output and output per capita; later we examine population growth.

The national savings rate is fixed at $s$ (the alternative assumption of intertemporal optimization would be straightforward as well, but with little gain in realism or insight). The price of investment goods relative to final output is $P_{I}$. Thus,

$$
s Q=P_{I} I
$$

The growth rate of the economy is then

$$
\gamma=\frac{1}{Q} \frac{\mathrm{d} Q}{\mathrm{~d} t}=\frac{1}{K} \frac{\mathrm{d} K}{\mathrm{~d} t}=\frac{s A}{P_{I}}-\delta
$$

Economic growth is positively dependent on the savings rate $(s)$ and the level of productivity $(A)$ and negatively dependent on the relative price of capital goods $\left(P_{I}\right)$ and the rate of depreciation $(\delta)$.

Transport costs affect the relative price of capital goods because some investment goods must be imported. In many developing countries, virtually all equipment investment is imported. To illustrate some implications of transport costs, we assume that each country produces a distinct final good and that investment is a composite of the final goods produced in various countries. The key assumption is that there are gains from trade so that transport costs and other barriers to trade 
reduce growth. We do not directly model the underlying reasons for specialization in production and, hence, gains from trade. As is well-known, specialization in production may result from different primary factor endowments, economies of scale in production, economies of specialization through learning by doing, or different technologies across countries because of investments in proprietary research and development.

Total investment depends on investment expenditure on domestic goods $\left(I^{d}\right)$ and on imported investment goods $\left(I^{m}\right)$ :

$$
I=I\left(I^{d}, I^{m}\right) .
$$

As a simple illustration, consider the case in which $I$ is a Cobb-Douglas function of the underlying domestic and foreign investment goods:

$$
I=\left(I^{d}\right)^{a}\left(I^{m}\right)^{(1-a)} .
$$

The true price index of investment goods, then, is a geometric average of the price of domestic and foreign investment goods. Setting the domestic good as numeraire (i.e., setting the price of $I^{d}$ equal to 1), we get:

$$
P_{I}=\alpha\left(P^{m}\right)^{(1-a)}
$$

where $\alpha=a^{a}(1-a)^{(1-a)}$.

We denote the (exogenous) world market price of the imported good as $P^{m_{*}}$ and write the landed (or c.i.f.) price in the home economy as $P^{m}=\tau P^{m_{*}}$, where $\tau>1$ is the c.i.f. factor (the world price plus cost, insurance, and freight). Then from equations 1 and 2 we have a modified equation for the growth of the economy: $:^{13}$

$$
\gamma=\left(\frac{s A}{\alpha}\right)\left(P^{m^{*}}\right)^{-(1-a)} \tau^{-(1-a)}-\delta .
$$

The growth rate is now inversely related to the cost of transport $(\tau)$. In this model, transport costs reduce growth by raising the cost of the imported capital good. Earlier empirical studies of growth (Barro 1991, for example) have shown that the rate of growth is a decreasing function of the relative cost of investment goods. This is essentially the channel by which the costs of transport and distance enter into equation 3 .

Equation 3 suggests three important points. First, underlying total factor productivity affects growth rates. Second, transport costs affect growth rates. These costs are likely to depend on several characteristics. Coastal economies will generally have much lower transport costs than hinterland economies. Countries near core economies (the main providers of capital goods) will generally have lower transport costs than distant countries, so growth is likely to diminish in direct proportion to distance from the core. Third, protectionist policies that raise the domestic price of imported capital goods, or that limit the exports needed to import capital goods, are likely to reduce long-term growth. This point cannot be overstated: countries require imports of capital goods for long-term growth. 


\section{A MODEL WITH INTERMEDIATE GOODS}

Suppose now that final production requires imported intermediate inputs. This assumption is of enormous empirical importance because many of the key manufactured exports of developing countries involve imported intermediate manufactured goods (fabrics, electronic components), which are then assembled domestically with low-cost labor and re-exported to world markets. The transport costs involved in the import of intermediate products and their re-export after domestic processing can affect the success or failure of manufacturing exports-even if the transport costs for investment goods are minimal.

We must now distinguish between gross output $(Q)$ and gross domestic product $(Y)$. In particular, we set

$$
Q=\min (A K, N / \mu)
$$

where $N$ is the intermediate good imported from abroad. The final good in the home market continues to be the numeraire (with price 1), and the relative price of the imported intermediate good is $P_{n}=\tau P_{n}^{*}$. The gross domestic product in units of the final good is given by

$$
Y=A K-P_{n} N=A K-\mu P_{n} A K
$$

or

$$
Y=\left(1-\mu P_{n}\right) A K .
$$

Because domestic final output in the home market is the numeraire, its price in the foreign market inclusive of transport costs is $\tau$. Similarly, if the intermediate product sells for $P_{n}$ in the home market, its price in the foreign market is $P_{n} / \tau$. Suppose that at world prices (i.e., in the foreign market) the share of the intermediate good in final output is given by $\sigma=\left(P_{n} / \tau\right) N /(\tau Q)$. Then equation 4 can be rewritten as:

$$
Y=\left(1-\sigma \tau^{2}\right) A K .
$$

All of the model goes through as before so that the modified growth equation is now

$$
\gamma=\left(\frac{s A}{\alpha}\right)\left(1-\sigma \tau^{2}\right)\left(P^{m}\right)^{-(1-a)}-\delta .
$$

The key point here is that relatively small transport costs can have huge effects on output and growth when the share of intermediate inputs in final demand is large. For example, suppose that $\sigma=0.7$. Now compare the growth rates of two countries, one with one-way transport costs equal to 5 percent of the value of gross output and one with those costs equal to 10 percent of the value of gross output. Ignore, for the moment, the transport costs for capital goods to focus solely on the effect of 
intermediate products. Let $\gamma_{1}$ be the growth rate of the low-transport-cost economy, and let $\gamma_{2}$ be the growth rate of the high-transport-cost economy. Then, from equation 5:

$$
\gamma_{1} / \gamma_{2}=[1-0.7(1.1025)] /[1-0.7(1.21)]=1.49 .
$$

The growth rate is 49 percent higher in the low-transport-cost economy than in the high-transport-cost economy even though the transport costs differ by only 5 percentage points. The explanation, of course, is that a "mere" 5 percentage point decrease in one-way transport costs for intermediate and final goods implies a whopping 49 percent increase in domestic value added.

The notion that intermediate inputs represent such a large portion of the value of gross output may seem unrealistic, but such is the case for many key export sectors in developing countries. In many labor-intensive industries—such as apparel and electronics assembly - the developing country imports a large portion of the value of final output. The intermediate imports are assembled by domestic workers and then re-exported to world markets. Thus, the developing country is essentially selling labor services used in assembly operations rather than selling the entire product. For such assembly industries, even small increases in transport costs can render the sector noncompetitive. For this reason, only developing countries with good transport access to world markets have been able to establish assembly-type industries (Radelet and Sachs 1998).

These arguments further underscore the disadvantages of the hinterland relative to the coast in economic development. Almost all modern production depends on multistage processing of output, with inputs often produced in many specialized enterprises, some foreign and some domestic. The low-cost transport of such intermediate products is crucial, especially in developing countries, where many intermediate components are imported. Only coastal areas or areas linked to the coast through navigable waterways or low-cost land transport have a chance to compete in such activities.

\section{DIVERGENCE, CONVERGENCE, AND POVERTY TRAPS}

The central feature of the AK model is the absence of convergence. Because there are no diminishing returns to investment in production, there is no tendency for growth to slow as capital deepening occurs. For this reason, countries that have underlying advantages in savings rates, efficiency, transport costs, or depreciation rates will display permanently higher growth rates. Moreover, the gap between such countries and slower-growing countries will widen.

Models such as the AK model also highlight another possibility. Suppose that transport costs are important in determining economic activity at one stage of history but then become less important. In the AK model, the early advantage would 
boost economic activity, causing the favored region to jump ahead of others. Once the advantage was lost, all countries would grow at the same rate (assuming the same $A, s$, and $\delta$ ). The early advantage would never be lost in terms of relative income levels, although growth rates would converge. In models with increasing returns to scale rather than the constant returns to scale of the AK model, the early advantage could lead to persistently higher growth rates even if it disappeared because growth rates could be a positive function of the level of capital, which would be raised by the transitory advantage. Thus, one possible interpretation of the observation that temperate-zone, coastal countries have the highest GDP is that such geographic attributes once conferred advantages, even if they no longer do so.

If the model is recast as a neoclassical growth model with diminishing marginal productivity of capital, so that $Q=A K^{\beta}$, with $\beta<1$, then the conclusions reached so far have to be recast as follows. The same list of parameters $\left(s, A, P^{m *}, \tau, \delta\right)$ now affect the steady-state level of $Q$, denoted $Q^{s s}$, and the steady-state capital stock, $K^{s s}$, but not the long-term growth rate. Because the capital stock converges gradually to its steady state, so too does the level of output. In this case, the growth equation can be written as follows:

$$
\gamma_{i}=\frac{1}{Q_{i}} \frac{\mathrm{d} Q_{i}}{\mathrm{~d} t}=\lambda\left(\ln Q_{i}^{s s}-\ln Q_{i}\right) .
$$

Equation 6 holds that the proportionate rate of growth depends on the gap between the steady-state level of output and the contemporaneous level of output. We could, in general, derive $\ln Q_{i}^{s s}$ to be a function of the underlying parameters. Approximating this relationship in $\log$-linear form, $\ln Q_{i}^{s s}=\boldsymbol{\beta}^{\prime} \mathbf{Z}_{i}$, where $\mathbf{Z}_{i}$ is the vector of underlying growth-influencing parameters and $\boldsymbol{\beta}$ is a vector of coefficients, we end up with an empirically estimable equation that has been extremely popular in recent years:

$$
\gamma_{i}=\lambda \boldsymbol{\beta}^{\prime} \mathbf{Z}_{i}-\lambda \ln Q_{i} \text {. }
$$

In this formulation, growth depends positively on the parameters in question and negatively on the initial income variable. The empirical presence of the term $\lambda \ln Q_{i}$ has been used to examine whether there is a tendency toward convergence, as in the neoclassical model, or continuing divergence, as in the AK model, in which the level of income is not a determinant of the rate of growth.

The issue of convergence or nonconvergence depends heavily on the underlying structure of production. In an environment of increasing returns to scale at the firm level as well as gains from a greater diversity of products-as in popular models of Dixit-Stiglitz imperfect competition (Romer 1986, 1990; Grossman and Helpman 1991) - there may well be increasing or at least constant returns to the capital stock at the macroeconomic level. The marginal productivity of capital would then be constant (as in the AK model), or even increasing, as the aggregate capital stock increases. In that setting, the AK model would depict the aggregate production 
technology better than the neoclassical model, with its assumption of declining marginal productivity of capital. Thus, to the extent that scale economies and product diversity are critical, we would expect to see little convergence between rich and poor countries, and we could well see divergence. To the extent that economies of scale and product diversity are limited, we would be more likely to see convergence in income levels, controlling for other factors.

\section{GEOGRAPHY AND POPULATION DYNAMICS}

Because it is not easy to integrate population dynamics with the AK model in a meaningful way, we have to step outside of that simple framework to discuss some aspects of the relationship among geography, population dynamics, and growth. We have stressed repeatedly the advantages of coastal areas for economic development, but we have not said anything about the distribution of populations across regions. In fact, the linkages are problematic for three reasons. First, vast numbers of people live in areas that are not suited to modern economic growth. Over the course of history, population densities have tended to rise in areas that are conducive to growth, so coastal areas are indeed more densely populated than hinterlands. But population densities also have risen in fertile agricultural areas-for example, along inland river systems such as the Ganges, Tigris, Euphrates, and Nile-that are useful for irrigation and inland trade but not international trade. As a result, population densities are high in areas that depend on subsistence agriculture and are not well suited to modern economic growth.

Second, since 1950, population growth has tended to be highest in poor, remote regions, mainly because population growth is negatively correlated with per capita income and highly negatively correlated with mothers' education and the market value of mothers' time. ${ }^{14}$ Thus, the concentration of populations in problematic regions is growing-exacerbated by the tendency for improvements in public health to spread more readily than economic growth.

Third, the mismatch between economic growth and population trends has caused mass migration from hinterlands to coasts. Most migratory movements are within poor countries, leading to unprecedented inflows of people into urban areas and to the rise of megacities in developing countries. The next largest migration most likely occurs across borders of developing countries. This type of migration includes vast flows of population from landlocked to coastal countries. The third largest migration is from poor to richer countries. This migration would, of course, be vastly larger were it not for immigration controls in the richer countries. In any case, the pressures for both internal and international migration will rise sharply in the coming decades as differences in income levels continue to increase.

The effects of population pressures on economic growth are likely to differ markedly between the hinterland and the coast. In the hinterland, transport costs are extremely high, the division of labor is low, and output is generally characterized by decreasing returns to scale in labor in the face of limited supplies of land. Thus, 
higher population densities will be associated with falling output per capita, a tendency seen in many African countries in the past twenty years. But on the coast, where transport costs are low and the division of labor is high, a rising population may be associated with stable or even increasing per capita incomes, even when the capital:labor ratio declines. This is because higher population densities make possible an increasingly refined division of labor. ${ }^{15}$

Thus, economies are likely to bifurcate on two pathways. The hinterland will experience decreasing returns to scale in labor and high rates of population growth. The coast will see increasing returns to scale in labor and falling rates of population growth as household incomes rise. The hinterland may therefore exhibit Malthusian dynamics, whereas the coast shows rising incomes and falling natural population growth rates. The two systems will interact through ever-greater pressures on migration from the hinterland to the coast.

\section{GEOGRAPHY AND ECONOMIC POLICY CHOICES}

So far we have stressed that geography may influence growth directly through the level of productivity and transport costs. Geography can have another potent effect through its influence on the choice of economic policies. Countries that are close to markets, for example, may choose more open trade policies than countries that are far from markets. We offer a motivation for such a possibility.

Suppose that growth is given by $s A / P_{I}$ and that $A$ can be decomposed into a multiplicative policy component, $\pi$, and a purely exogenous component, $\theta: s \pi \theta / P_{I}$. Suppose as well that $P_{I}=P_{I}(\tau)$, that is, the price of investment goods is an increasing function of transport costs. At this abstract level, we can say that the policy component of growth is a decreasing function of the ad valorem tax rate levied by the government on the private economy, $\pi=\pi(T)$. For simplicity we will use a linear functional form, $\pi=c-e T$. These taxes might be formal taxes, bribes demanded to clear customs, seizures of property, and so on. The basic idea is that government gains revenues but at the expense of a worsening policy environment.

Suppose that $T$ is chosen once and for all to maximize the expected utility of government officials. To keep matters simple in this abstract framework, we assume that the policy maker has an intertemporal log utility function, a pure discount rate of $d$, and a hazard rate $h$ of losing office. ${ }^{16}$ Expected utility is then given by

$$
E U=\int e^{-(d+h) t} \log [T Q(t)] d t .
$$

Equation 7 is maximized subject to the constraint that $Q(t)=Q_{0} e^{\gamma t}$, where $\gamma=$ $s \pi(T) \theta / P_{I}(\tau)$. What we have, essentially, is an optimal tax calculation on the part of the sovereign. Higher taxation yields more immediate revenue, but at the cost of slower future growth and hence lower future revenues. With simple manipulations, equation 7 can be rewritten as 


$$
E U=\left[\frac{\log T+\log Q_{0}}{d+h}\right]+\left[\frac{s \pi(T) \theta / P_{I}(\tau)}{(d+h)^{2}}\right]
$$

It then remains to calculate the optimal $T$ by setting $\mathrm{d} E U / \mathrm{d} T=0$. We find that

$$
T=P_{I}(\tau)\left(\frac{d+h}{s \theta e}\right) \quad T \leq 1 .
$$

This is an insightful expression. The optimal tax is an increasing function of transport costs, the discount rate, and the probability of losing office and a decreasing function of total factor productivity and the responsiveness of growth to the tax rate. Basically, the sovereign is trading quick gain for future loss. To the extent that growth is low (because $P_{I}$ is high or $\theta$ is low) or the future is heavily discounted (because $d+h$ is high) or unresponsive to taxation, the tax rate (T) should be set at a high level. To the extent that underlying growth is rapid or highly responsive to taxation, the tax rate should be set lower.

There are at least two implications for geography. First, good policy and good geography may tend to go together. When growth is inherently low because of adverse geographic factors and also unresponsive to policy (perhaps for the same reasons), the revenue-maximizing sovereign will impose high rates of taxation (such as protectionist policies). When the economy is inherently productive and responsive to good economic policies, the sovereign will have an incentive to impose low rates of taxation. The result is that natural differences in growth potential tend to be amplified by the choice of economic policies.

Second, the correlation between favorable underlying growth conditions and good policies leads to an important identification problem in estimating the effects of economic policy on economic performance. Suppose that a regression estimation of growth on taxation reveals a strong negative relationship. This is usually interpreted as a demonstration that policy matters for growth. We have just seen, however, that it might also reflect the fact that growth matters for policy. It is crucial to specify structural growth relationships that include both policy and underlying geography in order to disentangle these alternatives.

\section{EMPIRICAL LINKAGES BETWEEN GEOGRAPHY AND GROWTH}

The basic theory points to two geographic factors of deep significance for growth: transport costs, measured by the parameter $\tau$, and intrinsic productivity, measured by $A$. Consider transport costs first. Remarkably, despite the likely importance of transport costs for economic growth, there are no adequate measures of transport costs for a large sample of industrial and developing countries. The best that we could obtain for a large number of countries are International Monetary Fund (IMF) estimates of c.i.f./f.o.b. margins in international trade. These margins 
measure the ratio of import costs inclusive of insurance and freight (c.i.f.) to import costs exclusive of insurance and freight (f.o.b.). There are several problems with these measures, the most important being that they are only crudely estimated by the IMF and that they depend on the composition of imports and so are not standardized across countries.

Still, the c.i.f./f.o.b. margins are informative and predictive of economic growth. Using c.i.f./f.o.b. margins for 1995 (3.6 percent for the United States, 4.9 percent for Western Europe, 9.8 percent for East Asia, 10.6 percent for Latin America, and a whopping 19.5 percent for sub-Saharan Africa), we estimate an equation relating the margin to the country's distance from the core areas of the world economy and its accessibility to sea-based trade by including a dummy variable for nonEuropean landlocked countries: ${ }^{17}$

$$
\begin{aligned}
\text { c.i.f./f.o.b. }= & 1.06+0.010 \text { Distance }(1,000 \text { kilometers })+0.11 \text { Landlocked } \\
& (84.9) \quad(3.0) \\
\mathrm{n}=83, R^{2}= & .32 .
\end{aligned}
$$

As expected, there is a penalty both for distance from core economies and for being landlocked. Each 1,000 kilometers from the core raises the c.i.f./f.o.b. margin by 1.0 percentage point; being landlocked raises the c.i.f./f.o.b. margin by 11.1 percentage points. We show later that the c.i.f./f.o.b. margin is indeed predictive of income levels and economic growth. Interestingly, regressing the c.i.f./f.o.b. margin on the share of the population within 100 kilometers of the coast (Pop100km) yields a negative effect, but when both Pop100km and Landlocked are included, Landlocked has more explanatory power. The coefficient on Pop100km remains negative, as expected, but it drops in magnitude and is statistically insignificant.

We have seen that various regions differ markedly in terms of the locations of their populations relative to coasts and navigable rivers (see Table 1). Africans tend to live far from the coast, whereas Europeans are overwhelmingly coastal. The notion that coastal access has a large effect on trade and growth is plausible given what we know about the growth patterns of the most successful developing countries since 1965. Almost without exception, rapidly growing developing countries have based their growth on labor-intensive manufacturing exports. And almost without exception, such activities have expanded in port cities or export zones close to ports. Almost all countries that have achieved macroeconomic success in laborintensive manufacturing exports have populations almost entirely within 100 kilometers of the coast (Radelet and Sachs 1998).

The geographic determinants of the efficiency parameter, $A$, are potentially much more varied. First, we can surmise that coastal access will matter for internal trade and productivity as well as for international trade. Cities are engines of growth, and most large cities (other than garrison towns and administrative capitals) develop on coasts or on rivers that lead to the ocean. Thus, countries with neither coastlines nor ocean-navigable rivers tend to have less urbanization and less growth. A simple regression estimate for 149 countries shows that in 1995, ocean- 
accessible regions were indeed more urbanized, as were countries closer to economic core regions (LDistance). A simple regression reveals that

$$
\begin{aligned}
\text { Urbanization }= & 132.3+17.1 \text { Pop } 100 \mathrm{~km}-10.8 \text { LDistance } \\
& (10.8) \\
n=149, R^{2}= & .29 .
\end{aligned}
$$

A second major dimension of productivity linked to geography is the prevalence of infectious disease. Almost all of the 200 to 500 million annual cases of malaria occur in the tropics (see Map 4) (World Health Organization [WHO] 1997b). ${ }^{18}$ This pattern is neither accidental nor mainly a result of reverse causation, in which poor countries are unable to eradicate a disease that is under control in rich countries. There is no effective prophylaxis or vector control for malaria in areas of high endemicity, especially sub-Saharan Africa. Earlier methods of vector control are losing their effectiveness because of the increased resistance of mosquitoes to insecticides. Standard treatments also are losing effectiveness because of the spread of resistance to cloroquine and other antimalarial drugs.

The geographic extent of malaria is determined mostly by the ecology of the parasites (different species of malaria Plasmodia) and the vectors (different species of Anopheles mosquitoes). In temperate-zone and subtropical environments, where the foothold of the disease (both in terms of the mosquito population and the parasite endemicity) was more fragile, malaria has largely been under control since 1946. Since then, endemic malaria has retreated to the core tropics (see Map 5).

Using data from the World Health Organization, we construct a measure of malaria intensity (see Map 4). ${ }^{19}$ A simple regression of malaria intensity on ecological zones shows that it is most intense in the tropics and somewhat less intense in the subtropics (relative to all other ecozones). There is also a strong sub-Saharan Africa effect.

$$
\begin{aligned}
\text { Malarial intensity (scale } 0-1)=- & 0.01+0.3 \text { Wet tropics }+0.5 \text { Dry tropics } \\
& (0.7)(2.0) \quad(4.9) \\
+ & 0.4 \text { Wet subtropics }+0.2 \text { Dry subtropics } \\
& (3.9) \quad 0.5 \text { sub-Saharan Africa } \\
+ & (6.7) \\
n=148, R^{2}=.74 . &
\end{aligned}
$$

The pattern for malaria is a common one, fitting a range of infectious diseases whose vectors of transmission depend on the tropical climate. Many diseases that are carried by mosquitoes (dengue fever, yellow fever, and lymphatic filariasis, in addition to malaria), mollusks (schistosomiasis), and other arthropods (onchocerciasis, leishmaniasis, trypanosomiasis, Chagas's disease, visceral filariasis) are endemic in tropical ecological zones and nearly absent elsewhere. Although data on disease burdens by country are generally not available, the recent massive study 


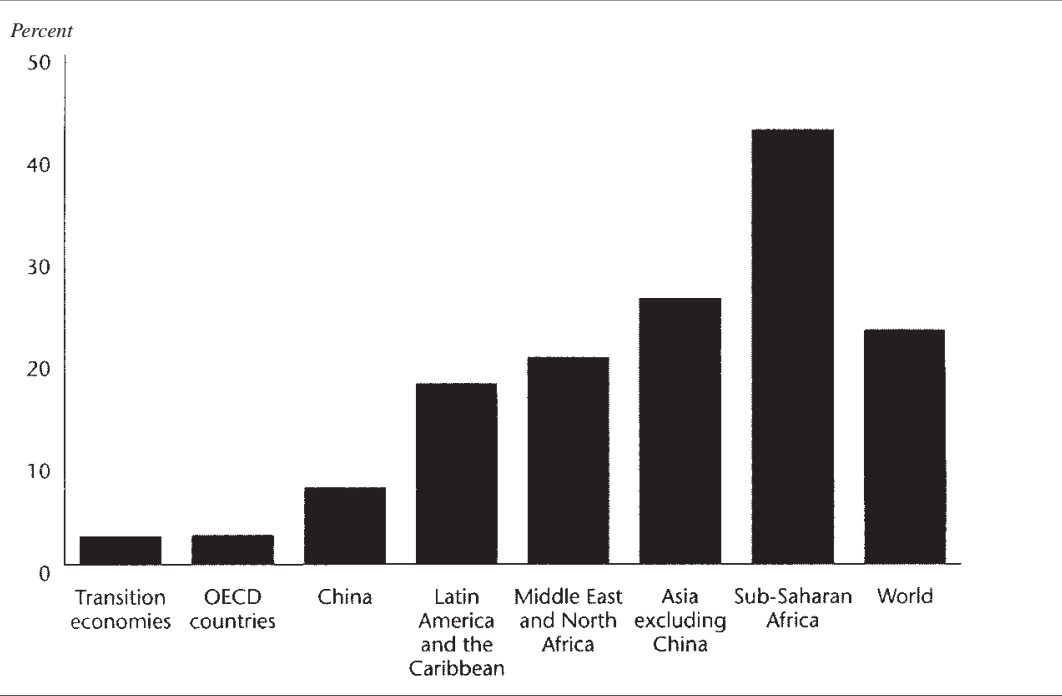

FIGURE 1. Infectious and Parasitic Disease as a Percent of Disability-Adjusted Life-Years Lost to All Causes

Source: Murray and Lopez (1996).

by Murray and Lopez (1996) on the burden of disease confirms that the heavy tropical concentration of infectious disease is an important cause of death (see Figure 1).

A third major correlate of geography and productivity is the link between climate and agricultural output. Estimates of agricultural productivity suggest a strong adverse effect of tropical ecozones on the market value of agricultural output after controlling for inputs such as labor, tractors, fertilizer, irrigation, and other inputs. Tropical agriculture suffers a productivity decrement of 30 percent to 50 percent relative to temperate-zone agriculture after controlling as best as possible for factor inputs (Gallup 1998).

Other more prosaic geographic correlates, such as endowments of high-value natural resources (hydrocarbons, minerals, precious gems), also affect crosscountry per capita income at a point in time. Lacking comprehensive measures of the international market value of such resource endowments, we settle for a rough measure of one key resource: deposits of petroleum and natural gas. Countries rich in hydrocarbon deposits per capita indeed display higher per capita income in 1995, although not necessarily higher economic growth. Indeed, Sachs and Warner (1995b) suggest that higher natural resource exports in 1970 (measured as a percentage of GDP) are negatively related to subsequent growth. 


\section{GEOGRAPHY AND LEVELS OF PER CAPITA INCOME}

We examine the linkage between output and geography both in levels and rates of change of GDP. Suppose that countries differ in their growth rates according to a vector of characteristics, $\mathbf{Z}$, that includes determinants of transport costs and total factor productivity. We write a linear approximation of a growth equation similar to equation 3 such that

$$
\gamma_{i t}=\boldsymbol{\beta}^{\prime} \mathbf{Z}_{i}+\mu_{i t} .
$$

In any period, $T>0, Q_{i t}=\exp \left(\gamma_{i} T\right) Q_{i 0}$. Suppose that in the distant past, $Q_{i 0}$ was randomly distributed across countries, with $\ln Q_{i 0}=\ln Q_{0}+\xi_{i}$, and with $\xi_{i}$ independent of $\mathrm{Z}_{i}$. We can then estimate a cross-country level equation of the form: ${ }^{20}$

$$
\ln \left(Q_{i T}\right)=\ln \left(Q_{0}\right)+T \boldsymbol{\beta}^{\prime} \mathbf{Z}_{i}+\varepsilon_{i}
$$

Note that the effects of the parameters $\mathbf{Z}_{i}$ on the level of $Q_{i T}$ will tend to grow over time, relative to $T$, because $\mathbf{Z}$ affects the growth rate, not merely the relative income level, of country $i$. Note also that if the $\mathbf{Z}$ variables are time dependent, then $Q_{i T}$ is a function of the entire time path of $\mathbf{Z}_{i}$. In general, for most variables of interest, we have snapshots of $\mathbf{Z}$ rather than a time series. One objective of empirical development studies should be to create time series measures of key institutional determinants of growth (such as openness of markets and protection of property rights) to strengthen our empirical tests.

We start with the simplest specification, writing the log level of per capita income as a function of three underlying geographic variables: Tropicar, the percentage of land in the geographic tropics; Pop $100 \mathrm{~km}$, the portion of the population within 100 kilometers of the coast; and LDistance, the minimum log distance of the country to one of the three core regions, measured as the minimum log distance to New York, Rotterdam, or Tokyo. We estimate this relationship three times: for Maddison's (1995) GDP estimates for 1950 and 1990 and for the World Bank's (1998) PPP GDP estimates for 1995 on the subset of countries for which Maddison's data are available (see Table 2). In all three regressions, output is a positive function of Pop100km and a negative function of Tropicar and LDistance. As expected, the magnitude of the effects tends to increase over time. In 1950, the "penalty" for Tropicar was -0.69 , indicating that per capita income in tropical areas was 50 percent $(=\exp [-0.69])$ of that in nontropical areas, controlling for the other factors. By 1995 , the effect had risen to -0.99 (or income of 37 percent of that in nontropical areas). Similarly, the benefit of a coastal population rose from 0.73 in 1950 to 1.17 in 1995. The implication is that being tropical, landlocked, and distant was already bad in 1950 and that it adversely affected growth between 1950 and 1995.

For the 1995 data, we have a wider range of possible explanatory variables. We start by estimating the simple level equation for GDP per capita on a PPP basis in 1995 for the 150 countries with populations greater than 1 million. We then turn to 
TABLE 2. Relationship between GDP per Capita and Selected Variables, 1950, 1990, and 1995

\begin{tabular}{|c|c|c|c|c|c|c|}
\hline Variable & $\begin{array}{c}(1) \\
\lg d p 50\end{array}$ & $\begin{array}{c}(2) \\
\operatorname{lgdp} 90\end{array}$ & $\begin{array}{c}\text { (3) } \\
\lg d p 95\end{array}$ & $\begin{array}{c}(4) \\
\lg d p 95\end{array}$ & $\begin{array}{c}(5) \\
\operatorname{lgdp95} \\
\text { non-Africa }\end{array}$ & $\begin{array}{c}(6) \\
\operatorname{lgdp} 95\end{array}$ \\
\hline Tropicar (percentage) & $\begin{array}{l}-0.69 \\
(4.13)\end{array}$ & $\begin{array}{l}-0.99 \\
(5.78)\end{array}$ & $\begin{array}{l}-0.99 \\
(5.10)\end{array}$ & & & \\
\hline Pop100km (percentage) & $\begin{array}{c}0.71 \\
(4.02)\end{array}$ & $\begin{array}{c}1.00 \\
(5.43)\end{array}$ & $\begin{array}{c}1.09 \\
(5.27)\end{array}$ & $\begin{array}{c}0.85 \\
(3.63)\end{array}$ & $\begin{array}{c}1.21 \\
(4.17)\end{array}$ & $\begin{array}{r}0.36 \\
(2.53)\end{array}$ \\
\hline LDistance & $\begin{array}{l}-0.22 \\
(2.56)\end{array}$ & $\begin{array}{c}-0.39 \\
(4.39)\end{array}$ & $\begin{array}{l}-0.34 \\
(3.41)\end{array}$ & & & $\begin{array}{c}0.03 \\
(0.55)\end{array}$ \\
\hline $\begin{array}{l}\text { c.i.f./f.o.b. } \\
\text { transport cost margin }\end{array}$ & & & & $\begin{array}{l}-2.28 \\
(2.32)\end{array}$ & $\begin{array}{r}-13.50 \\
(4.66)\end{array}$ & \\
\hline Malaria index 1994 (0-1) & & & & $\begin{array}{l}-1.55 \\
(6.60)\end{array}$ & $\begin{array}{l}-1.26 \\
(2.69)\end{array}$ & $\begin{array}{l}-1.15 \\
(7.65)\end{array}$ \\
\hline Hydrocarbons per capita & & & & $\begin{array}{c}0.01 \\
(1.84)\end{array}$ & $\begin{array}{c}0.01 \\
(1.75)\end{array}$ & $\begin{array}{c}0.01 \\
(1.85)\end{array}$ \\
\hline Socialism & & & & & & $\begin{array}{c}-0.05 \\
(0.31)\end{array}$ \\
\hline New state $(0-3)$ & & & & & & $\begin{array}{r}-0.06 \\
(0.98)\end{array}$ \\
\hline Openness (0-1) & & & & & & $\begin{array}{c}0.23 \\
(7.38)\end{array}$ \\
\hline Public institutions (0-10) & & & & & & $\begin{array}{c}0.55 \\
(3.17)\end{array}$ \\
\hline Constant & $\begin{array}{c}9.07 \\
(13.58)\end{array}$ & $\begin{array}{c}11.19 \\
(16.26)\end{array}$ & $\begin{array}{c}10.98 \\
(14.10)\end{array}$ & $\begin{array}{l}10.84 \\
(9.82)\end{array}$ & $\begin{array}{l}22.64 \\
(7.42)\end{array}$ & $\begin{array}{r}6.71 \\
(11.06)\end{array}$ \\
\hline Number of observations & 129 & 129 & 129 & 83 & 52 & 97 \\
\hline$R^{2}$ & .38 & .58 & .50 & .69 & .56 & .88 \\
\hline
\end{tabular}

Source: See appendix.

Note: Numbers in parentheses are the absolute values of robust $t$ statistics. GDP $=$ gross domestic product. c.i.f./f.o.b. $=$ the ratio of import costs inclusive of insurance and freight to import costs exclusive of insurance and freight.

growth equations for 1965 to 1990 . We group the explanatory variables $(Z)$ into three broad categories: variables related to transport costs and proximity to markets, variables related to ecological zone, and variables related to economic and political institutions.

In regression 4 of Table 2, we limit $\mathbf{Z}$ to a parsimonious set of four variables closely linked to geography: Pop100km, transport costs as measured by the c.i.f./f.o.b. margin, the prevalence of malaria, and the endowment of hydrocarbons per capita. These four variables alone account for 69 percent of the cross-country variation in per capita income, and all carry the expected sign and are statistically significant (although the endowment of hydrocarbons is significant only at the 10 percent level). High levels of GDP per capita are associated with low transport 
costs, a coastal population, a large endowment of hydrocarbons per capita, and the absence of malaria.

The strong correlation of malaria with income levels is not simply an "Africa proxy." When we rerun the equation for the sample of countries outside subSaharan Africa (regression 5 in Table 2), we find similar results. When we enter both malaria and Tropicar into the regression (results not shown), the effect of the malaria variable is far more important, suggesting that the negative effect of the Tropicar variable is largely subsumed by the geographic distribution of malaria. Of course, these associations are hardly proof of causality. Not only might the explanatory variables be proxies for left-out variables-for example, malaria could be a proxy for a range of tropical diseases or other liabilities-but there also could be reverse causation, in which high incomes lead to the control of malaria or to a reduction in transport costs.

Regression 6 in Table 2 includes a vector of variables related to political and economic institutions: Socialism, which is a dummy variable for socialist economic institutions; New state, which measures the proportion of time under colonial rule; Openness, which measures the proportion of time between 1965 and 1990 that the country was open to international trade; and Public institutions, which measures the quality of government institutions. Consistent with many recent studies, we find that openness and the quality of public institutions are highly correlated with the level of income. Socialism is not significant, probably because of the strong collinearity with Openness and because of the smaller data set once the Public institutions variable is included (because that variable is not available for most of the socialist economies). Newly independent countries also do not have significantly lower income levels. If the malaria index is not included, the New state variable is highly significant, which suggests that the heavy burden of disease in tropical Africa and Asia made these regions more susceptible to colonization.

Thus, we find that both policy and geography variables are strongly correlated with 1995 GDP per capita. Geography may be even more important than is suggested by this equation because there are reasons to believe that favorable geography plays a role in inducing growth-promoting institutions-such as open trade and an efficient public bureaucracy—a linkage examined briefly below.

\section{GEOGRAPHY AND GROWTH OF PER CAPITA INCOME}

We now examine the forces of convergence and divergence by estimating a cross-country growth equation that allows for the possibility of catching-up effects. Specifically, we estimate a model of average annual growth during 1965 to 1990 conditional on per capita income levels in 1965. (The dates are determined by data availability. For the growth equations, we use Summers and Heston [1994] for our measures of PPP-adjusted GDP per capita.) We test whether growth is affected by the initial income level (negatively in the case of convergence or positively in the 
TABLE 3. Relationship between GDP Growth and Selected Variables

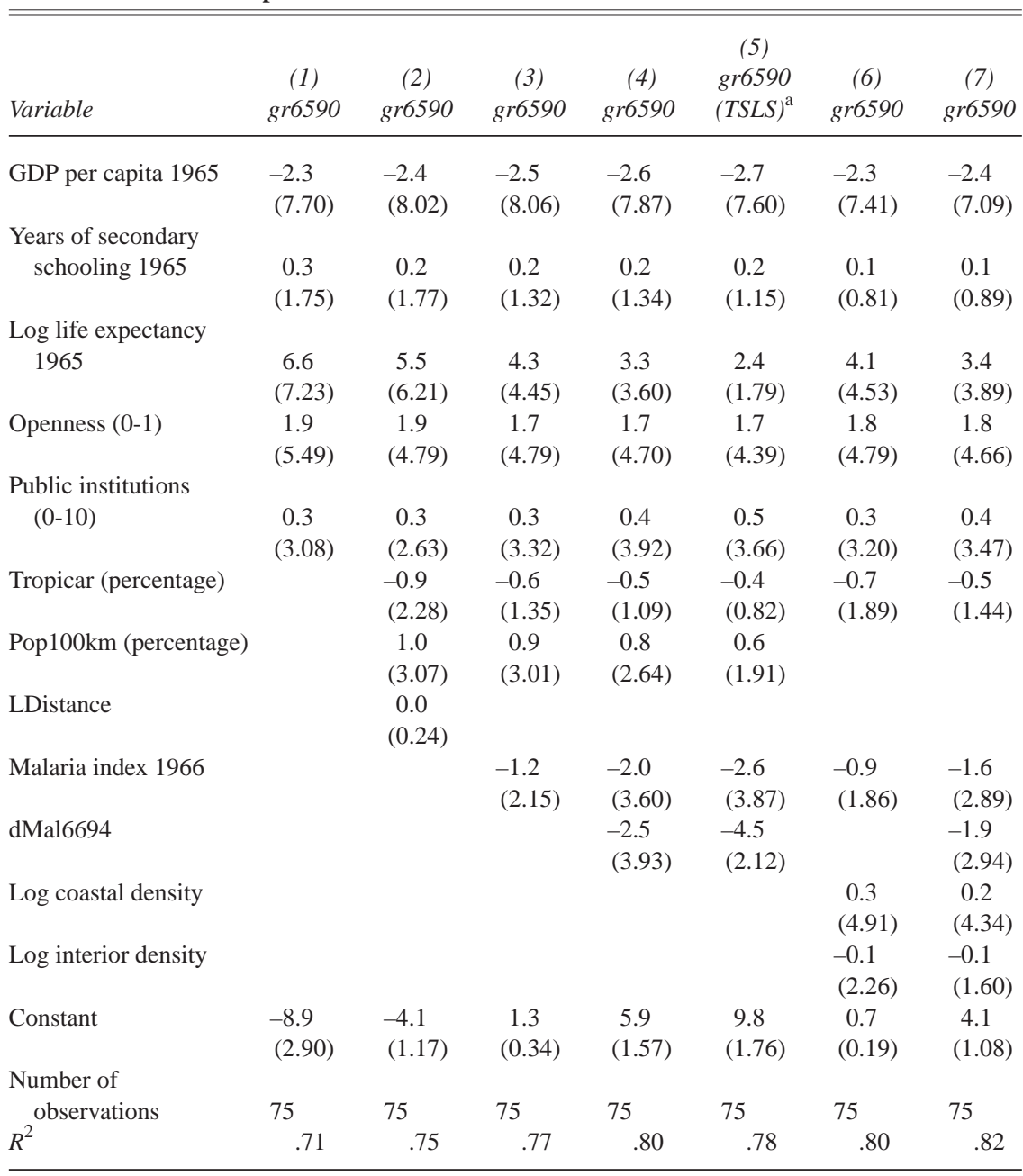

Source: See appendix.

Note: Numbers in parentheses are absolute values of robust $t$ statistics. GDP $=$ gross domestic product. a. Two-stage least squares.

case of divergence) as well as by geographic variables, holding constant initial income and other policy and institutional variables (see Table 3).

We start with a baseline equation similar to those in Barro and Sala-i-Martín (1995), in which average annual growth between 1965 and 1990 is a function of initial income in 1965, initial education level in 1965 (measured by average years of secondary school among the population), log of life expectancy at birth in 1965, 
openness of the economy to international trade, and quality of public institutions (see regression 1 in Table 3). ${ }^{21}$ We find evidence for conditional convergence and standard results for the other variables: output is an increasing function of education, life expectancy, openness, and the quality of public institutions. In regression 2 of Table 3 we add Tropicar, Pop100km, and LDistance. Tropicar and Pop100km are highly significant and of the expected sign. All other things being equal, annual growth is 0.9 percentage points lower in tropical countries than in nontropical countries. Annual growth in landlocked countries $($ Pop100km $=0)$ is 1.0 percentage point lower than in coastal countries. Interestingly, the LDistance variable is not significant, suggesting that distance to the economic core may be subsumed by other variables. Indeed, countries closer to the core economies tended to be more open and have better public institutions. If we drop those two variables, LDistance has the expected negative sign and is statistically significant (not shown).

In regression 3 of Table 3, we drop LDistance and add a measure of malaria at the beginning of the period. ${ }^{22}$ Initial malaria prevalence is strongly correlated with poor economic performance. Countries that had severe malaria in 1966 grew 1.2 percentage points a year slower than countries without falciparum malaria, even after controlling for life expectancy. The estimated effect of being in the tropics becomes smaller than it was without the malaria variable and insignificant. Clearly, the malaria variable is picking up the explanatory power of the tropics variable. The effect of initial life expectancy is also reduced, although it remains large and significant.

The effect of malaria is accentuated if we also account for changes in malaria over the period. Countries that had severe malaria but reduced its prevalence grew more rapidly than countries that were not able to control it. We use the malaria index for 1994 and calculate the change in malaria in the intervening period, dMal6694. In regression 4 of Table 3, countries with severe malaria and no change in malaria are estimated to have grown 2.0 percentage points slower than countries free of $\mathrm{fal}$ ciparum malaria, other things being equal. Countries that had severe malaria in 1966 but eradicated it by 1994 are estimated to have grown 2.5 percentage points faster than countries with malaria, or slightly ( 0.5 percentage points) faster than countries without malaria.

None of the countries in the sample with 100 percent of their land area subject to falciparum malaria was able to eradicate it during this period, however. Reductions in malaria were largest in the countries with the least malaria in 1966 (see Table 4). (Temperate ecozones were effectively free of falciparum malaria in 1966.) Reductions in malaria occurred in desert (nontemperate) ecozones and the subtropics, whereas the malaria index increased slightly in tropical ecozones.

The change in malaria incidence could be partly due to economic growth, if growth provided countries with the economic and institutional resources to carry out effective control programs. To account for the possible impact of economic growth on malaria reduction, we instrument the malaria change with four subtropical ecozone variables and two desert tropical ecozone variables. ${ }^{23}$ Regression 5 in 
TABLE 4. Levels and Reductions in Malaria Prevalence between 1966 and 1994, by Ecozone

\begin{tabular}{lcc}
\hline \hline Ecozone & Malaria Index 1966 & $\begin{array}{c}\text { Average Reduction } \\
\text { (percentage) }\end{array}$ \\
\hline Temperate $(n=57)$ & 0.2 & -0.2 \\
Desert $(n=23)$ & 27.8 & -8.8 \\
Subtropical $(n=42)$ & 61.7 & -5.0 \\
Tropical $(n=21)$ & 64.9 & 0.5 \\
\hline
\end{tabular}

Source: See appendix.

Note: Countries are classified by their predominant ecozone: temperate (temperate, boreal, and polar ecozones), desert (tropical and subtropical deserts), subtropical (nondesert subtropical), and tropical (nondesert tropical). The index and average reduction are unweighted averages over countries.

Table 3 shows that the estimated impact of malaria on growth increases when change in malaria is instrumented. There is no indication that faster growth is the cause of malaria reduction. Some of the countries with the largest increases in malaria, such as India and Sri Lanka, had steady, if unspectacular, economic growth over this period. Likewise, some countries with dramatic decreases in malaria, such as Namibia, had almost no economic growth. Only after controlling for other relevant variables can the effect of malaria reduction on growth become apparent.

The index of malaria, and malaria change, may be more than just a measure of malaria. It may be picking up the prevalence of other tropical diseases not well indicated by average life expectancy and tropical area. Among tropical diseases, malaria is widely recognized to be the most important. But the malaria index also may be a proxy for scourges such as onchocerciasis, filariasis, and trypanosomiasis.

Malaria occurs throughout the tropics but is concentrated in sub-Saharan Africa, where 90 percent of the estimated cases occur each year (WHO 1997b). Moreover, sub-Saharan Africa is the only region where falciparum malaria predominates. When the region is left out of regression 5 (not shown), the malaria coefficients fall to about half their size in the full sample and the estimates lose statistical significance (although the change in malaria from 1966 to 1994 is significant at the 7 percent level). With the loss of fifteen sub-Saharan countries from the sample, it is not possible to obtain accurate estimates of the effect of the tropics and the effect of malaria separately. When Tropicar is left out of the non-African regression, both initial malaria and change in malaria are significant at the 5 percent level.

In regression 6 of Table 3, we test for agglomeration effects. The basic idea is to see how economic growth depends on the scope of the market. A plausible measure of the scope of the market is GDP per square kilometer within the economy in the initial year, 1965. We separate GDP per square kilometer on the coast and GDP per square kilometer in the hinterland because population density on the coast is likely to be associated with an increased division of labor and increasing returns, whereas 
population density in the hinterland is likely to be associated with diminishing returns. Note that $\operatorname{lnGDP}$ density $=\operatorname{lnGDP}$ per square kilometer $=\operatorname{lnGDP}$ per capita $+\ln$ Population per square kilometer. And because lnGDP per capita is already a regressor, we can enter population density or GDP density interchangeably into the regression. For countries whose entire population is within 100 kilometers of the coast, the population density of the hinterland is entered as 0 . For countries whose entire population is more than 100 kilometers from the coast, the population density of the coastal region is entered as 0 . We also drop Pop $100 \mathrm{~km}$ as a separate regressor because it is highly collinear with the two population density variables. Note that we use 1994 measures of Pop100km and 1965 population levels for the country as a whole to calculate the population densities in coastal and hinterland regions.

The regression estimate is revealing. We now find that higher coastal population density is associated with faster growth, whereas higher hinterland population density is associated with lower growth. Thus, economies of agglomeration appear to be at play in coastal regions, although they are not powerful enough to overcome the other tendencies toward conditional convergence in income levels. Large populations appear to be a net disadvantage for hinterland economies, which must rely more on their natural base and have few opportunities to absorb population through manufacturing and international trade based in cities.

With separate inland and coastal agglomeration effects in regression 6, the estimated effect of malaria becomes less precise, slipping to a 7 percent significance level. In contrast, if initial malaria and malaria change are included in regression 7 , they are both strongly significant, but the diminishing returns of population density in the hinterland lose statistical significance. We are pushing the limits of the degrees of freedom in our data, but the results suggest that both malaria prevalence and inland population concentrations are detrimental to growth.

Several conclusions emerge from these equations:

- Both geography and policy matter. Geography is not necessarily destiny, but more than good policy is needed to foster economic growth.

- The tropics are not conducive to growth. This effect seems to be strongly related to the presence of malaria, which may be a proxy for a range of tropical maladies geographically associated with that disease.

- Coastal regions are good for growth. Access to the coast seems to matter because it lowers transport costs and creates agglomeration economies.

- High population density appears to be conducive to growth on the coast and inimical to growth in the hinterland.

- Distance from core markets is not an important determinant of economic growth.

What are the regional implications of these findings? Sub-Saharan Africa is especially hindered by its tropical location, high prevalence of malaria, small portion of people living near the coast, and low population density near the coast. Europe, North America, and East Asia, by contrast, have been favored on all four counts. 
TABLE 5. Growth Rates in Selected Regions Relative to East Asia

\begin{tabular}{lccc}
\hline \hline Variable & Sub-Saharan Africa & South Asia & Latin America \\
\hline Growth & -4.2 & -2.8 & -3.6 \\
Explained & -3.7 & -2.0 & -3.0 \\
Initial GDP & 1.4 & 1.0 & -1.1 \\
Geography and health & & & \\
$\quad$ Total & -3.0 & -0.8 & -0.2 \\
$\quad$ Coastal density & -0.7 & 0.0 & -0.5 \\
Interior density & 0.0 & -0.3 & 0.1 \\
$\quad$ Tropicar & -0.1 & 0.1 & -0.1 \\
$\quad$ Malaria index & -1.0 & -0.1 & 0.3 \\
$\quad$ Life expectancy & -1.2 & -0.5 & 0.0 \\
Policy and education & & & -1.8 \\
$\quad$ Total & -2.1 & -2.1 & -1.0 \\
Openness & -1.2 & -1.2 & -0.7 \\
Public institutions & -0.7 & -0.9 & 0.0 \\
$\quad$ Secondary education & -0.2 & -0.1 & -0.6 \\
Residual & -0.5 & -0.8 & \\
\hline
\end{tabular}

Source: Regression 7 in Table 3.

Note: GDP = gross domestic product.

South Asia is burdened by its largely tropical location, large portion of people living in the hinterland, and the high population density there. The transition economies of Eastern Europe and the former Soviet Union, many of which are landlocked, have suffered from their small share of population living near the coast and low population density near the coast. But they have benefited from their lack of exposure to tropical disease. Finally, Latin America is moderately coastal but with relatively low coastal population densities. Moreover, Latin America is moderately exposed to the problems of the tropics, including malaria.

The growth rates of sub-Saharan Africa, South Asia, and Latin America are decomposed, using regression 7 in Table 3. The deviation of each region's growth from that of East Asia is shown in Table 5. In sub-Saharan Africa, geography and health factors are estimated to reduce growth by 3.0 percentage points a year, more than policy and education factors. In South Asia, geography and health factors reduce growth by -0.8 percentage points a year. And in Latin America, geography and health factors explain almost none of the shortfall in growth relative to East Asia. As we suggest in the next section, this accounting may understate the real role of geography because economic policies are likely to be a function of geography.

\section{GEOGRAPHIC EFFECTS ON ECONOMIC POLICIES}

As noted, geography may affect economic policies by altering the trade-offs facing government. A coastal economy, for example, may face a high elasticity of 
output response with respect to trade taxes, whereas an inland economy does not. As a result, a revenue-maximizing inland sovereign may impose harsh trade taxes, whereas a coastal sovereign would not. In this section, we briefly explore this idea, focusing on the effect of geography on the choice of protection or openness to trade in 1965 through 1990.

The first step is to check the underlying notion that the responsiveness of growth to openness depends on geography. So far, we have entered the openness and geography variables in a linear manner, not allowing for interactions. To check the possibility of interactions, we estimate the basic regression equation for three sets of countries—all, coastal (Pop100km = 0.5), and hinterland (Pop100km < 0.5) —and check the coefficient on the openness variable. Because we lose degrees of freedom in this exercise, we estimate the bare-bones growth equation in which annual average growth between 1965 and 1990 is a function of initial income, openness, malaria in 1966, the change in malaria between 1966 and 1995, and the log of life expectancy in 1965. The results for the openness coefficient are as follows: for all economies ( $n=92), \beta=2.6(t=6.8)$; for coastal economies $(n=46), \beta=3.3(t=$ $6.5)$; and for hinterland economies $(n=46), \beta=1.4(t=2.5)$. The responsiveness of growth to trade seems to be more than twice as high in coastal economies.

The next step is to see whether coastal countries are more likely to choose open trade policies. We do so by regressing the extent of openness during 1965 through 1990 on Land within $100 \mathrm{~km}$ of the coast, Tropicar, and the initial income level:

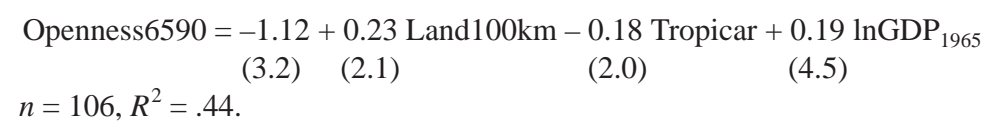

These results imply that coastal economies may be more likely to adopt open trade policies. This is certainly evident in East Asia, where economies such as the Republic of Korea, Malaysia, Taiwan (China), and Thailand opened themselves to trade in the early 1960s, long before other developing countries did so. The early liberalizers, on the whole, were coastal economies. Still, the results are at best suggestive and should be tested more carefully.

\section{POPULATION DISTRIBUTION AND ECONOMIC ACTIVITY}

The distribution of population around the world is far from uniform. In some regions, large expanses of land are virtually uninhabited, whereas almost all the land in Europe and coastal South and East Asia is farmed or occupied by towns or cities. Differences in population density at different latitudes are dramatic (see Figure 2).

Two types of geographic features seem to support high population densities. First are features that favor dense agricultural settlements, such as arable soil, inland rivers for local transport and irrigation, and climatic and ecological systems conducive to rice cultivation (which supports an especially high labor intensity of 


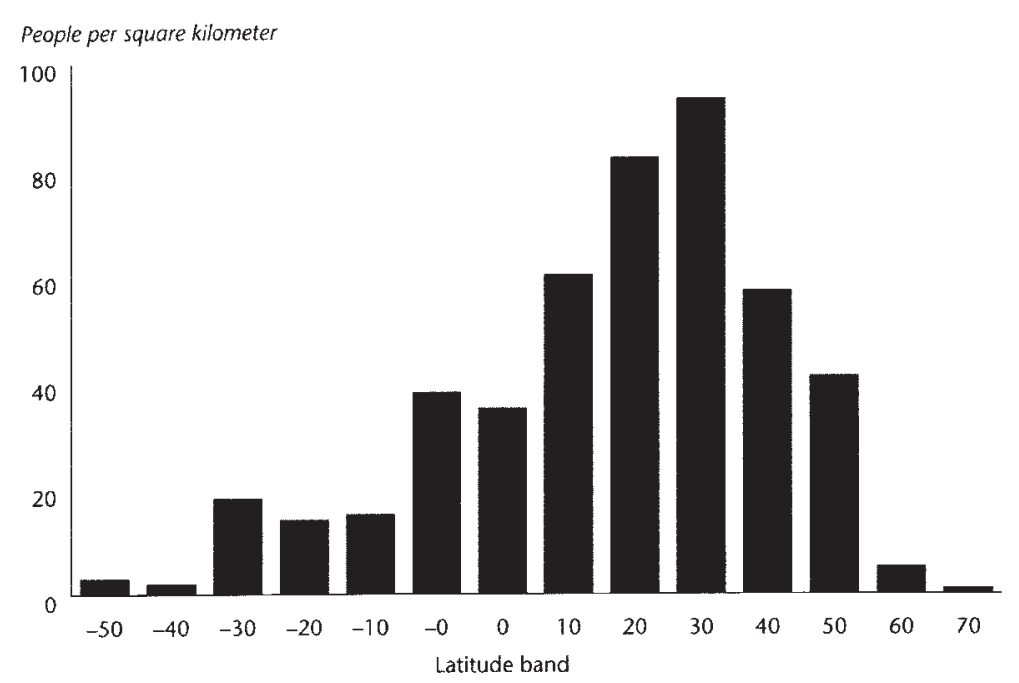

FIGURE 2. Population Density by Latitude

Source: See appendix.

production relative to other grains). Second are features that support modern economic growth, such as access to the coast (and thereby to international trade). Because population densities have a long time dependence, the current distribution of world population was heavily influenced by demographic trends well before the period of modern economic growth. As a result, population density across regions remained almost unchanged between 1800 (see Map 6) and 1994 (see Map 2). Broadly speaking, global population patterns reflect suitability for agriculture more than suitability for modern economic growth. And the legacy of low population densities in the New World persists despite several centuries of emigration from the Old World.

The biggest changes have occurred in the lands of new settlement: the Americas, Australia, and New Zealand. These parts of the world had been cut off from other continents and did not have plant and animal species that could easily be domesticated to produce high yields. Thus, they could not support the large population concentrations of Eurasia (Diamond 1997). European settlers, having devastated the sparse indigenous populations through conquest and the spreading of unfamiliar diseases, had not yet grown to large numbers by 1800 .

The geographic conditions conducive to dense agrarian populations are often very different from those conducive to economic growth. In particular, agriculture depends more on access to fresh water than on access to the ocean. Over time, this has led to high concentrations of inland populations that are now substantially cut 
off from international trade. And as noted earlier, dynamics of population change may exacerbate biases toward high inland concentrations. In richer regions, rising incomes have reduced fertility, making population growth self-limiting. But in rural areas with poorer economic growth prospects, population growth rates are among the highest in the world.

Regions where geography supports high population densities but not economic growth are the sites of the most severe and intractable poverty. Inland China, northcentral India, central Asia, and inland Africa are all far from world trade and dependent on labor-intensive agriculture, with significant disadvantages for modern economic growth. Severe endemic disease burdens, especially in Africa, add to the geographic obstacles. The role of geography in shaping the distribution of population can be seen in the simple population growth identity. Current population depends on the population at some point in the past and the growth rate during the intervening period:

$$
P_{i 1}+P_{i 0} e^{r i T}
$$

where $P_{i 1}$ is the current population density in location $i, P_{i 0}$ is past population density, $r_{i}$ is the instantaneous growth rate, and $T$ is time elapsed between period 0 and period 1 . The population growth rate in each location, $r_{i}$, depends on geography as well as on initial population. If $r_{i}$ is not allowed to depend on the initial population density, then current population is always exactly proportional to past population. The population growth rate is given by

$$
r_{i}=g \ln P_{i 0}+\gamma \ln \mathbf{X}_{\mathbf{i}}
$$

where $g$ and $\gamma$ are parameters and $\mathbf{X}_{\mathbf{i}}$ is a vector of geographic characteristics. Taking $\operatorname{logs}$ of equation 8 and adding an error term $\varepsilon_{i}$,

$$
\ln P_{I 1}+(1+g T) \ln P_{i 0}+\gamma \ln \mathbf{X}_{\mathbf{i}}+\varepsilon_{i} .
$$

We can regress the current population density on an initial population density (say, in 1800) and geographic characteristics, all in logs, using equation 9. The first coefficient will tell us the degree of persistence in population density. If the coefficient is less than $1, g$ is negative: higher-density regions grow slower. This is a measure of "convergence" of population density across space, similar to convergence in economic growth equations. The second set of coefficients tells us the impact of geography on population density given the initial density (i.e., the impact of geography on population growth in the past 200 years). If we take the initial point at the time of the first appearance of humans ( $T^{\prime} \cong 500,000$, according to Diamond 1997), then $P_{i 0}^{\prime}$ and

$$
\ln P_{i 1}=\gamma^{\prime} T^{\prime} \ln \mathbf{X}_{\mathbf{i}}+\varepsilon_{i} .
$$

The coefficient vector estimated from this specification tells us the unconditional impact of geography throughout time on current population densities. 
Equations 9 and 10 are estimated using the following geographic features: accessibility to coast and rivers, elevation, prevalence of malaria, soil qualities and water availability, and ecozones (see Table 6). (The variables and their sources are explained in the appendix.) Several clear patterns emerge.

- Proximity to inland or ocean-navigable rivers is an important predictor of population density, more important than proximity to the coast.

- Good soil and water supply are important factors in population density.

- Population densities are highest in the moist temperate ecozone.

- Population density is greater at high altitudes in the tropics but lower at high altitudes in the temperate zone.

- The prevalence of malaria is positively correlated with population density.

- There is tremendous persistence in relative population density over the centuries, but there is also some convergence toward a more uniform density. (The coefficient on population density in 1800 is positive and less than 1.)

- After taking into account all geographic factors, population densities are much higher in Eurasia and lower in the Americas, Australia, and New Zealand.

The tendency of populations to cluster near non-ocean-navigable inland rivers (rather than on the coast or near ocean-navigable rivers) is directly contrary to the importance of these rivers for economic output. This tendency, together with the clustering of populations in areas of good soil and water (especially soil and water suitable for rice cultivation) and in more agriculturally productive ecozones, suggests that an area's suitability for agriculture has been the driving force behind population distribution. The distribution of population near rivers rather than near the coast is striking when the regressions are done by region (not shown). In South Asia, the former Soviet Union, Western Europe, and East Asia, population densities near coasts are lower than elsewhere, conditional on their distance to rivers. In Western Europe and East Asia, populations had the good fortune to cluster near rivers navigable to the sea, whereas South Asian populations have poor access to waterborne trade. Latin America is the only region with a higher concentration of population on the coast than near rivers. The highest population densities that are far from coasts and from ocean-navigable rivers are in central Africa, South Asia (especially the Gangetic Plain), inland China (with heavy concentrations in the river valley systems and Manchuria), and Central Asia, including Iran, Iraq, Anatolia, and countries near the Caspian Sea (see Map 7).

The much higher population densities at higher altitudes in the tropics could be due to the less hostile disease environment there because many tropical disease vectors are sensitive to altitude and temperature. But this explanation seems inconsistent with the positive correlation between population density and malaria. In individual regions, population densities are (statistically) significantly lower in malarial areas in all regions except Africa, where population is much denser in malarial areas. If Africans in malarial areas have built up partial immunities to 
TABLE 6. Impact of Geography on Log Population Density, 1994

\begin{tabular}{|c|c|c|}
\hline Variable & $\begin{array}{c}\text { Impact of Geography } \\
\text { on Population Density } \\
\text { Given Population in } 1800(1)\end{array}$ & $\begin{array}{c}\text { Overall Impact of } \\
\text { Geography on } \\
\text { Population Density (2) }\end{array}$ \\
\hline Log population density 1800 & $\begin{array}{c}0.612 \\
(79.63)^{* *}\end{array}$ & \\
\hline Eurasian continent & & $\begin{array}{c}1.136 \\
(28.15)^{* *}\end{array}$ \\
\hline Lands of new settlement & & $\begin{array}{c}-0.998 \\
(23.73)^{* *}\end{array}$ \\
\hline \multicolumn{3}{|l|}{ LDistance (kilometers) to: } \\
\hline Coast & $\begin{array}{l}-0.040 \\
(2.26)^{*}\end{array}$ & $\begin{array}{l}-0.145 \\
(8.13)^{* *}\end{array}$ \\
\hline Ocean-navigable river & $\begin{array}{l}-0.113 \\
(6.28)^{* *}\end{array}$ & $\begin{array}{c}-0.188 \\
(10.2)^{* *}\end{array}$ \\
\hline Inland river & $\begin{array}{c}-0.324 \\
(26.48)^{* *}\end{array}$ & $\begin{array}{c}-0.235 \\
(18.4)^{* *}\end{array}$ \\
\hline \multicolumn{3}{|l|}{ Log elevation in temperate zone } \\
\hline Less than 1,000 meters & $\begin{array}{c}0.018 \\
(1.35)\end{array}$ & $\begin{array}{c}0.096 \\
(6.77)^{* *}\end{array}$ \\
\hline 1000 to 2,000 meters & $\begin{array}{c}0.859 \\
(9.63)^{* *}\end{array}$ & $\begin{array}{c}1.108 \\
(11.67)^{* *}\end{array}$ \\
\hline More than 2,000 meters & $\begin{array}{c}-1.361 \\
(12.83)^{* *}\end{array}$ & $\begin{array}{l}-0.279 \\
(8.47)^{* *}\end{array}$ \\
\hline \multicolumn{3}{|l|}{ Log elevation in tropics } \\
\hline Less than 1,000 meters & $\begin{array}{l}-0.034 \\
(6.47)^{* *}\end{array}$ & $\begin{array}{c}0.034 \\
(7.28)^{* *}\end{array}$ \\
\hline 1,000 to 2,000 meters & $\begin{array}{l}1.801 \\
(6.04)^{* *}\end{array}$ & $\begin{array}{c}2.133 \\
(6.2)^{* *}\end{array}$ \\
\hline More than 2,000 meters & $\begin{array}{c}0.846 \\
(3.2)^{* *}\end{array}$ & $\begin{array}{c}1.296 \\
(3.15)^{* *}\end{array}$ \\
\hline Malaria (fraction of area) & $\begin{array}{c}0.109 \\
(2.48)^{*}\end{array}$ & $\begin{array}{c}2.104 \\
(4.72)^{* *}\end{array}$ \\
\hline \multicolumn{3}{|l|}{ Soil and water } \\
\hline Rice-growing land (fraction of area) & $\begin{array}{c}1.064 \\
(10.44)^{* *}\end{array}$ & $\begin{array}{c}1.335 \\
(13.41)^{* *}\end{array}$ \\
\hline Soil suitability $(0-100)$ & $\begin{array}{c}0.127 \\
(21.47)^{* *}\end{array}$ & $\begin{array}{c}0.134 \\
(22.25)^{* *}\end{array}$ \\
\hline Log stream density ${ }^{\mathrm{a}}$ (number per cell) & $\begin{array}{c}0.144 \\
(17.77)^{* *}\end{array}$ & $\begin{array}{c}0.192 \\
(23.42)^{* *}\end{array}$ \\
\hline \multicolumn{3}{|l|}{ Ecozones (relative to moist temperate) ${ }^{\mathrm{b}}$} \\
\hline Polar and boreal & $\begin{array}{c}-2.273 \\
* *\end{array}$ & $\begin{array}{c}-3.202 \\
* *\end{array}$ \\
\hline Desert & $\begin{array}{c}-1.224 \\
* *\end{array}$ & $\begin{array}{c}-1.840 \\
* *\end{array}$ \\
\hline Dry temperate & $\begin{array}{c}-0.176 \\
* *\end{array}$ & $\begin{array}{c}-0.409 \\
* *\end{array}$ \\
\hline Very wet temperate & $\begin{array}{c}-1.204 \\
* *\end{array}$ & $\begin{array}{c}-1.539 \\
* *\end{array}$ \\
\hline
\end{tabular}


TABLE 6 Continued

\begin{tabular}{lcc}
\hline \hline Variable & $\begin{array}{c}\text { Impact of Geography } \\
\text { on Population Density } \\
\text { Given Population in 1800 (1) }\end{array}$ & $\begin{array}{c}\text { Overall Impact of } \\
\text { Geography on } \\
\text { Population Density (2) }\end{array}$ \\
\hline Dry tropical & -0.380 & -0.494 \\
Wet tropical & $* *$ & $* *$ \\
Number of observations & -0.932 & -1.257 \\
$R^{2}$ & 13,976 & $* *$ \\
\hline
\end{tabular}

Source: See appendix.

Note: The regressions included constants that are not reported. Numbers in parentheses are absolute values of robust $t$ statistics.

a. Stream density is the count of streams in each 1 degree cell from satellite data.

b. Includes thirty-six ecozones (moist temperate ecozone is excluded). The reported estimates are the average of ecozone coefficients within each ecozone group. “**” below the coefficient means that each of the constituent coefficients were statistically different from zero at the 1 percent level.

$* p=.05 . * * p=.01$

malaria, they may not seek to avoid infection by moving to nonmalarial areas that may have other disadvantages (such as lack of water). Given the strong negative correlation between malaria and income levels, the higher population density in malarial areas is extremely worrisome.

There may be long-term geographic explanations for the high population densities in Eurasia. As noted, Diamond (1997) argues that Eurasia's east-west axis, which runs along rather than across ecozones, has allowed the movement of crop varieties, ideas, and goods. He speculates that Eurasia had the best selection of native plants and animals, whereas the lands of new settlement (the Americas, Australia, and New Zealand) had the least conducive flora and fauna for original domestication. Until the modern era, new lands were physically isolated from the rest of the world and so were cut off from the diffusion of technology, ideas, and trade that permeated Eurasia. Africa also suffered from isolation and from a northsouth axis that hindered the diffusion of Eurasian innovations and crop varieties.

Population in the lands of new settlement heavily reflects the equilibrium between the economic productivity of those regions and income levels in the European sending countries. Much of the indigenous population was exterminated by conquest and disease soon after its first contact with Europeans; since then, incomes of the settlers have generally been somewhat higher than incomes of Europeans considering migration to distant lands. Although incomes in North America, Australia, and New Zealand have remained on par with those in Western Europe, the costs of distance mean that population densities are much lower than in Europe (the eastern United States comes closest to being an exception). Africa, by contrast, resisted European conquest until the end of the nineteenth century, largely because of the high rate of mortality from malaria and tropical diseases for would-be European explorers and conquerors (Curtin 1989). Once quinine was applied as a 
prophylaxis for malaria, Europe subjugated most of Africa. But except in the temperate southern and northern extremes, few Europeans settled in Africa. Thus, the low productivity of the land in Africa was reflected in low population densities and low incomes.

\section{RESEARCH DIRECTIONS AND POLICY IMPLICATIONS}

One skeptical reviewer of an early draft of this article said, "Fine, but we knew all this in seventh-grade geography." We have three responses. First, that is not really true. Seventh-grade geography does not attempt to quantify the advantages or disadvantages of various regions in a systematic way, holding constant other determinants of economic performance. Second, even if it is true, that learning is lost somewhere on the way to graduate school. The vast majority of articles on economic development and growth in the past decade have neglected even the most basic geographic realities in cross-country analyses. In considerable writing on Africa, for example, many socioeconomic variables have been tested for their effects on growth. But little attention has been paid to the implications of the large portion of landlocked countries, the disease environment, the harsh climate and its effects on agriculture, or the implications of low population densities in coastal areas. Third, the policy implications of these findings, if the findings are true, are staggering. Aid programs should be rethought, and the crucial issue of migration should be brought into much sharper focus.

The research agenda needs to be reshaped in light of the importance of geographic variables. We know precious little about the underlying relationships between climate and agricultural productivity, disease vectors, and public health. Not only do we not know the costs of malaria in terms of economic development but we barely know the quantitative extent of the disease. Cause-of-death data are not available for most developing countries and even fewer data are available on illness. We lack basic data on transport costs that are comparable across countries and, even more important, within countries between hinterlands and urban areas. By neglecting geographic variables, we may overstate the role of policy variables in economic growth and neglect some deeper obstacles (although, because policy variables are often so poorly measured in cross-country work, there is an inherent downward bias due to measurement errors).

The following research questions deserve much greater scrutiny:

- How do transport costs differ across countries? How much of these differences are related to policy (port management, road maintenance), market structure (pricing by shipping cartels), or physical geography (allowing inland, coastal, or oceanic trade)? How are transport costs likely to change as a result of new information technologies, better intermodal transport, and other trends? 
- What is the burden of disease on economic development? What are the channels of effects, that is, the direct and indirect costs of infant and child mortality, adult morbidity, and premature death? What are the main channels of morbidity-direct effects, interactions with other diseases, interactions with nutrition? To what extent do different burdens of disease reflect policy (i.e., provision of public health services), resource availability for health spending, or intrinsic geographic factors such as the ecology of disease vectors?

- To what extent are differences in agricultural productivity a result of policy (taxation of agricultural inputs and outputs), quality of inputs, scope and scale of agricultural research, and intrinsic geophysical and biological conditions?

- How are fertility decisions affected by geography? Do sub-Saharan Africa's high fertility rates result from low population densities in rural areas, limitations of nonagricultural activities in the hinterland, policy decisions or limitations (such as lack of adequate family planning), or institutional arrangements (such as communal land tenure, which may lead to externalities in family size)?

Gaining a better grasp of these issues will lead to a next step of analysis that looks at the extent to which transport costs, disease burdens, agricultural productivity, and population growth and density affect overall economic performance. Consider, for example, the relatively straightforward issue of transport and communications costs. It might be assumed that falling transport costs would favor the hinterland, which is burdened by high transport costs. But Krugman and Venables (1995) have shown that a drop in transport costs from high to moderate levels can hurt a high-cost region by giving even greater benefit to a medium-cost region. Consider our simple setup in equation 3 . Suppose that there are two economies with different transport costs and that $\tau_{i}=\exp \left(d_{i} \mu\right)$, where $d_{i}$ is the distance of economy $i$ from the core economy and $\mu$ is a transport cost parameter that declines over time. Suppose that there is a "near" and a "far" economy, with $d^{n}<d^{f}$. When $\mu$ is high, both economies have zero growth. When $\mu$ is 0 , both have equal and high growth. It is when $\mu$ takes a mid-range value that growth rates differ, with the near economy growing faster than the far economy. Thus, even when we know how transport costs differ and how they are likely to evolve, we need an accurate spatial model to understand the implications.

Of course, the policy implications of these geographic considerations must be informed by clearer research results. Even now, however, we can identify several areas of public policy that almost surely should be adjusted. First, the special problems of landlocked countries and hinterland populations within coastal countries deserve closer scrutiny. The twenty-eight landlocked countries outside Europe, containing 295 million people in 1995, are among the poorest in the world, with an average per capita income of $\$ 1,673$. In many cases, the infrastructure linking these countries to world markets is seriously deficient. Coastal countries harass landlocked countries, neglect the road networks that would link them to the coast, or impose punitive effective taxation through transit and port charges. In some cases, 
heated political clashes have taken place between interior and coastal countries. Bolivia and Chile, for example, still lack diplomatic relations 119 years after the War of the Pacific cost Bolivia its coastline. Aid programs to improve transport infrastructure linking landlocked countries to ports almost necessarily require the cooperation of several countries. Crucial infrastructure aid for Rwanda, for example, includes the repair and maintenance of the Kenyan road from Nairobi to Mombasa, which transports Rwandan and Ugandan tea to the Indian Ocean. Such crossnational needs are hard to coordinate and are often neglected by country-based donor efforts. Policy makers should also pay more attention to transport conditions for hinterlands within national economies, such as Uttar Pradesh in India, where more than 140 million people live several hundred kilometers from the coast.

Second, policy makers should examine the likelihood and desirability of largescale future migrations from geographically disadvantaged regions. Suppose that sizable populations face local cost or disease conditions that prohibit economic growth. The result is likely to be growing pressures for mass migration, first within countries, then across national borders, and finally internationally. We have not yet studied the linkage between geography and migration, although it is painfully evident that the linkage is strong. Consider landlocked Bolivia, for example. Some 15 percent to 20 percent of Bolivians live in neighboring countries, especially Argentina. About a third of Burkinabés live in Ghana, Côte d'Ivoire, and elsewhere. Throughout southern Africa, there are large, relatively uncontrolled population movements across national boundaries. The consequences of these movements are becoming increasingly complex and often deleterious as AIDS and other diseases spread and environmental and public health institutions prove unable to cope.

Third, to the extent that the arguments in this article are correct, they cast a dramatic light on current population trends. We have shown that future population increases are likely to be largest precisely in the most geographically distressed economies. According to United Nations population projections, the highest projected growth rates between 1995 and 2030 are in regions that are least coastal, most tropical, and most distant from the core economies (see Map 8). If we regress the projected population growth on geographic characteristics, we find that

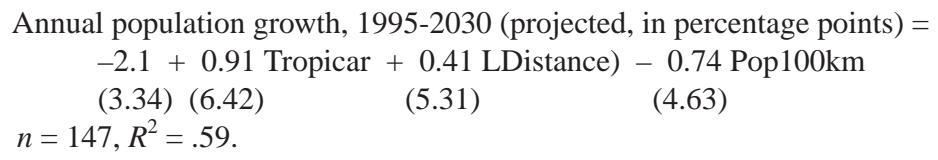

Inland countries (Pop100km $=0$ ) have projected annual population growth rates that are 0.74 percentage points a year higher than those in coastal countries (Pop100km $=1)$. Tropical countries have projected population growth rates that are 0.91 percentage points higher than those in nontropical countries.

Population pressures in inland and tropical areas are likely to intensify pressures for mass migration. Thus, a more urgent review of population policy is required. A certain calm has descended over this policy area on the questionable grounds that 
population growth does not matter for per capita income growth. We have seen the half-truth of this assessment: it may be true for coastal countries engaged in the international division of labor, but it is most likely untrue for the geographically distressed regions where population increases will be most dramatic.

Finally, donors should reexamine the balance of aid between policy-based lending to individual governments - which is the most popular form-and greatly enhanced aid for basic research on tropical agriculture and tropical public health. Our results suggest that the tropics are damned not just, or even mainly, by bad policies but by difficult inherent conditions. If this is the case, the relentless focus on policy reform may be misguided. A more effective approach to controlling malaria might do more to improve the economic environment—and incidentally, might improve policy by enhancing the incentives for good policies facing the sovereign. Many of the core issues in tropical health and agriculture are prime examples of international public goods that require a concerted scientific and financial commitment far beyond that available from any single government. The coordinated agricultural research aid effort is seriously underfunded; the situation in tropical public health is even more desperate.

\section{APPENDIX DATA DEFINITIONS AND SOURCES}

This appendix defines the variables used in the analysis and gives the data sources.

\section{DEPENDENT VARIABLES}

Gross domestic product (GDP) per capita. Purchasing power parity (PPP)-adjusted GDP per capita in 1950 and 1990 are from Maddison (1995, Tables D1 and F4). PPPadjusted GDP per capita in 1995 are from World Bank (1998). When World Bank (1998) data were not available, U.S. Central Intelligence Agency (CIA) data were used. Data from CIA (1996) were used for Afghanistan, Albania, Cambodia, Cuba, Eritrea, Iraq, Democratic People's Republic of Korea, Kuwait, Liberia, Libya, Somalia, Sudan, Tanzania, former Yugoslav Republic of Macedonia, and Yugoslavia (Serbia/Montenegro). Data from CIA (1997) were used for Bosnia and Herzegovina, Bhutan, Brunei, Djibouti, Equatorial Guinea, French Guiana, Myanmar, and Taiwan (China). Additional data for countries in Map 1 are from CIA (1997).

GDP growth. Instantaneous growth rates of PPP-adjusted GDP per capita from 1965 to 1990 are from the Penn World Tables 5.6 (Summers and Heston 1994).

TRANSPORT COST AND MARKET PROXIMITY MEASURES 
Land100km. The proportion of a country's land area within 100 kilometers of the coast, excluding coastline in the Arctic and sub-Arctic regions above the winter extent of sea ice. Data are from the National Geographic Society (NGS 1995) for sea ice, and the World Data Bank II (ESRI 1996b) for digital coastlines.

Pop $100 \mathrm{~km}$. The proportion of a country's population in 1994 within 100 kilometers of the coast (as defined for Land100km). The data for population distribution in 1994 come from the first detailed geographic information system world population data set (shown in Map 2), described in Tobler et al. (1995).

Pop100cr. The proportion of a country's population in 1994 within 100 kilometers of the coast or an ocean-navigable river, excluding coastline in the Arctic and sub-Arctic regions above the winter extent of sea ice and the rivers that flow to it. Rivers were classified as ocean navigable mainly according to descriptions in Rand McNally and Co. (1980), Britannica Online (1998), and Encyclopedia Encarta (1998). (Precise information on the classification of river systems is available from the authors.) Coastlines and ocean-navigable rivers (displayed in Map 7) are calculated from digital coastlines in ESRI (1996b) and rivers in ESRI (1996a). The population data are as for Pop100km.

Coastal density. Coastal population/coastal square kilometers $=($ population $\times$ Pop $100 \mathrm{~km}) /$ (land area $\times$ Land $100 \mathrm{~km}$ ). The unit is people per square kilometer.

Interior density. Interior population/interior square kilometers $=$ [population $\times(1-$ Pop100km $)] /$ [land area $\times(1-$ Land $100 \mathrm{~km})]$. The unit is people per square kilometer.

Landlocked, not in Europe. Excludes landlocked countries in Western and Central Europe (Austria, the Czech Republic, Hungary, former Yugoslav Republic of Macedonia, Slovakia, and Switzerland). Includes the Eastern European countries of Belarus and Moldova.

LDistance. The log of the minimum Great-Circle (air) distance in kilometers to one of three capital-goods-supplying regions: the United States, Western Europe, or Japan, measured as distance from the country's capital city to New York, Rotterdam, or Tokyo.

c.i.f./f.o.b. shipping cost margin. The ratio of c.i.f. import prices to f.o.b. import prices as a measure of transport costs from International Monetary Fund data (Radelet and Sachs 1998).

\section{OTHER GEOGRAPHIC VARIABLES}

Tropicar. The proportion of a country's land area within the geographic tropics. Calculated from ESRI (1996b).

Malaria index 1966. Index of malaria prevalence based on a global map of the extent of malaria in 1966 and the proportion of falciparum malaria, from the World Health Organization (WHO 1967). The percentage of each country's land area subject to malaria was calculated from the digitized 1966 map shown in Map 5 ("some risk" areas excluded). The inten- 
sity of malaria is captured by the percentage of cases that were the malignant falciparum strain in 1990 (WHO 1992). For African countries without 1990 falciparum data, we used WHO (1997a) data (in which almost all African countries with malaria are described as predominantly falciparum, which we classified as 100 percent). The index is the product of the percentage of land area subject to malaria times the percentage of falciparum malaria cases.

Malaria index 1994. Constructed in the same way as the malaria index for 1966, based on a global malaria map for 1994 (WHO 1997b) and the percentage of falciparum malaria in 1990.

Hydrocarbons per capita. Log of British thermal units per person of proven crude oil and natural gas reserves in 1993, from the World Resources Institute (WRI 1996).

Southern hemisphere. Indicator for countries wholly below the equator, as well as Brazil, Democratic Republic of Congo, Republic of Congo, Ecuador, Gabon, Indonesia, and Kenya.

Land area. Area in square kilometers, excluding submerged land. All data are from World Bank (1997) except for data on Mexico and Taiwan (China), which come from CIA (1997).

\section{OTHER ECONOMIC, SOCIAL, AND POLITICAL VARIABLES}

Openness. Proportion of years a country was open to trade during 1965 through 1990, based on criteria established in Sachs and Warner (1995a). An economy is considered open if it meets minimum criteria on four aspects of trade policy: average tariffs must be lower than 40 percent, quotas and licensing must cover less than 40 percent of imports, the black market premium must be less than 20 percent, and export taxes must be moderate.

Public institutions. The quality of public institutions is based on the ICRGE index described in Knack and Keefer (1995) that averages five indicators of the quality of public institutions, including the perceived efficiency of the government bureaucracy, the extent of government corruption, the efficacy of the rule of law, the presence or absence of expropriation risk, and the perceived risk of repudiation of contracts by the government. Each country is scored on these five dimensions, based on surveys of business attitudes within the countries. The subindexes on the five measures are then summed to produce a single, overall index that is scaled between 0 and 10 .

New state. The timing of national independence ( 0 if before 1914, 1 if between 1914 and 1945, 2 if between 1946 and 1989, and 3 if after 1989), from CIA (1996).

Socialism. Equal to 1 if the country was under socialist rule for a considerable period during 1950 through 1995, based on Kornai (1992).

Life expectancy 1965. Data are from United Nations (1996).

Years of secondary schooling 1965. Data are from Barro and Lee (1993). 
Urbanization. Percentage of population living in urban areas in 1995, from World Bank (1998).

War-torn. Countries that participated in at least one external war during 1960 through 1985, from Barro and Lee (1994), with additional countries classified by the authors.

Population. Total population in millions, from World Bank (1997).

\section{ONE DEGREE BY ONE DEGREE POPULATION DATABASE}

The data for population in 1994 come from the first detailed geographic information system world population data set (seen in Map 2), described in Tobler et al. (1995). We aggregated the $5^{\prime}$ by $5^{\prime}$ cells to $1^{\circ}$ by $1^{\circ}$ cells, creating about 14,000 observations. The world population distribution in 1800 comes from McEvedy and Jones (1978), mostly on a countrywide basis. The geographic data come from a variety of sources. The incidence of malaria for each $1^{\circ}$ cell was digitized from a WHO (1997b) map for 1994. The distance of each cell from the coast was calculated from World Data Bank II coastal boundaries (ESRI 1996b). These boundaries were edited to remove the coasts north of the winter extent of sea ice, as in Land100km above. Ocean-navigable rivers were classified as in Pop100cr above. Inland rivers are rivers classified as navigable by ESRI (1996a) but with no outlet to the sea, as well as rivers navigable to the sea but not navigable by ocean-going vessels. Elevation data are derived from the ETOPO world elevation database (National Oceanic and Atmospheric Administration [NOAA] 1988). Land used for rice-growing was derived from the ArcAtlas database on agriculture (ESRI 1996a). Soil depth and stream density (a count of the streams in each $1^{\circ}$ cell from satellite data) come from NOAA (Sellers et al. 1997). Soil suitability for rainfed crops was derived from the Food and Agriculture Organization (FAO 1995). A classification of land areas into thirty-seven ecozones comes from Leemans (1990).

\section{NOTES}

1. These figures refer to the unweighted average of gross domestic product (GDP) per capita in China, Hong Kong, Indonesia, the Republic of Korea, Malaysia, the Philippines, Singapore, Taiwan, and Thailand.

2. The term geographic tropics refers to the area between the Tropic of Cancer $\left(23^{\circ} 45^{\prime}\right.$ north latitude) and the Tropic of Capricorn ( $23^{\circ} 45^{\prime}$ south latitude), the band in which the sun is directly overhead at some point during the year.

3. All data are described in the appendix. Population data are based on geographic information system modeling, with a resolution of five minutes by five minutes. Some of the underlying database is less refined, however, with population interpolated to the five minute by five minute grid.

4. Among the 150 countries with populations greater than 1 million, the correlation between population density and GDP per capita in 1995 was 0.32 .

5. We include the U.S. and Canadian regions bordering the Saint Lawrence Seaway and Great Lakes. 
6. We have not yet assembled subnational GDP data. Therefore, to make the calculation, we assume that GDP per capita is identical in all regions within a country. This approach understates the size of GDP in coastal regions because GDP per capita tends to be higher in those regions.

7. These eleven economies, in declining order of shares in global exports, are the United States (20.0), Japan (20.0), Germany (14.6), France (6.4), the United Kingdom (5.8), Italy (4.9), Canada (4.7), the Republic of Korea (3.2), Taiwan, China (2.9), Belgium (2.7), and the Netherlands (2.5). Other major exporting economies that are closely linked to the core production system include Singapore (4.3), China (2.7), Mexico (2.3), Malaysia (2.2), and Hong Kong, China (0.7).

8. There is an inconsistency in our classification because tropics is based on land area in the geographic zone but subtropics is defined according to ecozone. We rely on the geographic definition of the tropics both for convenience and because of its empirical relevance in the regression estimates. Because there is no comparable geographic definition of the subtropics, we fall back on an ecozone definition.

9. The landlocked countries in Western and Central Europe are Austria, the Czech Republic, Hungary, the former Yugoslav Republic of Macedonia, Slovakia, and Switzerland.

10. Using geographic information system data, we calculate the coastal population in two ways. First, we take all land area within 100 kilometers of the open sea (except coastline in the Arctic and subArctic regions above the winter extent of sea ice) (National Geographic Society [NGS] 1995) and measure the population in that area. Second, we identify river systems that accommodate ocean-going vessels on a regular basis and add land areas within 100 kilometers of such rivers. Because we do not have direct transport costs for these river systems, there are inevitably difficulties in classification; some rivers that accommodate ocean-going vessels impose high costs for such transport. Due to the classification difficulties and the greater empirical relevance of coastal access alone, population and land area near navigable rivers are not used in the rest of the article. (Information on the classification of river systems is available from the authors.) We experimented with a number of distance measures, all of which produced similar outcomes. We therefore choose the simplest: the shortest distance between the country capital and New York, Rotterdam, or Tokyo.

11. The key recent reference on cross-country growth is Barro and Sala-i-Martín (1995), which, like hundreds of recent cross-country growth studies, makes no reference to economic geography. One recent (and nearly lone) exception is Hall and Jones (1996), which notes that countries' economic productivity (measured by GDP per capita) increases with distance from the equator.

12. Smith (1976) does not discuss culture and economic development in detail in An Inquiry into the Nature and Causes of the Wealth of Nations, but it seems clear that, like other thinkers of the Scottish Enlightenment, he viewed human nature as universal and did not view culture as a primary differentiating factor in economic development. For example, Smith never bemoans the lack of entrepreneurial zeal in one place or another as an explanation for poor economic performance. Later thinkers, such as Max Weber, put great stress on culture, although the alleged linkages are difficult to document and test. More recently, Landes (1998) argues that culture, in addition to geography and institutions, should be given pride of place in explaining differences in economic performance.

13. Suppose that instead of Cobb-Douglas, the investment function is a constant elasticity of substitution (CES) function of the underlying investment in each country: $I=\left(\Sigma \bigcirc_{I} I_{j}^{-\varepsilon}\right)^{-1 / \varepsilon}$. The elasticity of substitution is $\sigma=1 /(1+\varepsilon)$. In that case, the price index $P_{I}$ also is a CES of the prices of the individual investment goods, of the form $P_{I}=\left[\Sigma \mu_{j}^{\sigma}\left(\tau_{j} P_{j}^{*}\right)^{(1-\sigma)}\right]^{1 /(1-\sigma)}$. Thus, if the investment function has an elasticity of substitution of $s$, then the price index has an elasticity of substitution $1 / \sigma$. When $\sigma$ equals 1 , so that the investment function is Cobb-Douglas, the price index is also Cobb-Douglas, with

$$
P_{I}=\Pi v P_{j}^{a j}=\Pi v\left(P_{j}^{*}\right)^{a_{j}} \tau_{j}^{a j}, v=a_{1}^{a_{1}} a_{2}^{a_{2}} \mathrm{~K} a_{n}^{a_{n}} .
$$

The growth rate of the home country depends on a geometric weighted average of transport costs from each of its capital suppliers, with the weight equal to the share of investment goods from $j$ in the total investment expenditure of the home country. When the elasticity of substitution among investment goods 
is infinite, the CES price index has zero elasticity and takes the form $P_{I}=\min \left\{\tau_{j} P_{j}^{*} / \mu_{j}\right\}$. What counts in that case is not a weighted average of prices but rather the lowest price adjusted for the productivity of the various investment goods. The relevance for geography would be as follows: assuming that the efficiency-adjusted price of capital goods is equal in all markets (i.e., $P_{j}^{*} / \mu_{j}$ is the same across all markets), growth would depend on the minimum distance to one of the capital goods suppliers rather than the average distance to all the capital goods suppliers. In practice, transport costs would depend on the minimum distance to a major market—-the United States, Western Europe, or Japan—rather than the average distance to the United States, Europe, and Japan. In our empirical work, we find that the specification of minimum distance to a major capital goods supplier outperforms the average distance to all major capital goods suppliers.

14. Caldwell (1982), in particular, has argued that population pressures are likely to remain high in rural areas while falling sharply in urban areas. According to Caldwell, children represent net economic assets in peasant rural areas because they can assist in household production from an early age, do not generally require high expenditures on education, and can be counted on to care for parents in old age. In an urban setting, however, children represent net economic costs because they are likely to attend school rather than contribute to household production and, because of urban mobility, are much less reliable as social security for elderly parents. Moreover, the opportunity costs of raising children are much higher, especially if women are part of the urban labor force.

15. The standard model of traditional agriculture is based on a neoclassical production function of the form $Q=Q(L, \mathbf{F})$, where $L$ is labor input and $\mathbf{F}$ is a vector of other farm inputs, including land. Output per capita falls as $L$ rises relative to $\mathbf{F}$. For the modern sector, the increasingly popular model of differentiated production makes $Q$ a function of $n$ intermediate products $X_{i}$, each produced with labor $L_{i}$, so that $Q=\left(\Sigma X_{i}^{\gamma}\right)^{(1 / \gamma)}$, with $0<\gamma<1$. Under conditions of monopolistic competition, free entry, and costless introduction of new product varieties, it is typically shown that $X_{i}$ is fixed by profit-maximizing firms at a given production run $x$, with $L_{i}=a+b x$. For a total labor force $L=\Sigma L_{i}$, we have $n(a+b x)=L$, or $n=$ $L /(a+b x)$. Production is then $\left(\sum x^{\gamma}\right)^{(1 / \gamma)}=n^{(1 / \gamma)} x=L^{(1 / \gamma)} x(a+b x)^{-(1 / \gamma)}$. The result is that production shows increasing returns to labor. Output per capita is therefore a rising function of $L$.

16. There is an instantaneous probability, $h$, of losing office. The probability distribution for tenure in office is then $\mathrm{f}(t)=h e^{-\mathrm{ht}}$, and the mean time in office is $1 / h$.

17. The data refer to unweighted country averages for the respective regions for countries for which International Monetary Fund (IMF) data are available.

18. The great range of uncertainty about the number of cases is indicative of the lack of concerted study and monitoring of malaria by international organizations in recent years.

19. Because of lack of reliable data on the incidence or prevalence of malaria in the most severely affected countries, our index is necessarily approximate. We digitized a world map of the extent of malaria in 1994 (shown in Map 5) from the World Health Organization (WHO) (1997b) and used the geographic information system to calculate the percentage of a country's land area subject to malaria, excluding areas of "some risk." To quantify the differing intensity of malaria, we collected WHO (1992) data for 1990 on the percentage of malaria cases that are the malignant falciparum species of malaria, which has the most severe symptoms, is the most resistant to drugs, and is responsible for almost all malaria deaths. The malaria index is the product of the percentage of land area times the percentage of falciparum cases. As discussed below, falicparum malaria is predictive of low economic growth but non-falicparum malaria is not.

20. The random term $\varepsilon_{i}$ is a function of the initial error term $\zeta_{i}$ as well as of the intervening sequence of disturbances $\left\{\mu_{i t}\right\}_{t=0, \ldots, T}$. Ordinary least squares estimation would require that the error terms be independent of $\mathbf{Z}_{i}$.

21. Growth is measured as $(1 / 25) \times\left(\operatorname{lnGDP}_{1990}-\operatorname{lnGDP}_{1965}\right) \times 100$.

22. The malaria index at the start of the $1965-1990$ period is constructed in a manner similar to that for the malaria index for 1994. We digitized a malaria map for 1966 (shown in Map 5) from WHO (1967) to calculate the percentage of a country's land area subject to malaria. The malaria index is the product of 
the percentage of land area times the percentage of falciparum cases in 1990. The mix of falciparum, vivax, and other species of malaria in a given ecozone is not likely to depend much on vector control or public health measures, nor is it likely to change over time. For instance, sub-Saharan Africa has always had almost 100 percent of the malignant falciparum, whereas the temperate regions that once had malaria had almost no falciparum.

23. The first stage regression of ecozones on the change of malaria (with $t$-statistics in parentheses) is

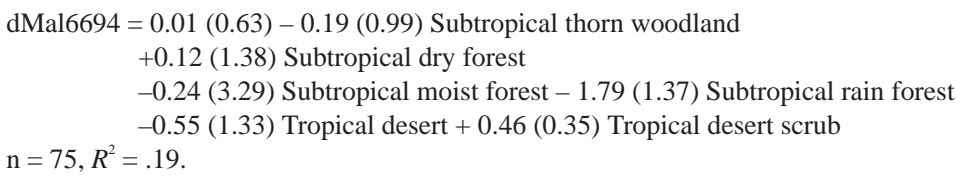

\section{REFERENCES}

Barro, Robert J. 1991. Economic growth in a cross-section of countries. Quarterly Journal of Economics 106 (2): 407-43.

Barro, Robert J., and Jong-Wha Lee. 1993. International comparisons of educational attainment. Journal of Monetary Economics 32: 363-94.

—. 1994. "Data set for a panel of 138 countries." Retrieved from the World Wide Web: http://www.nber.org/pub/barro.lee/ascii/readme.txt

Barro, Robert J., and Xavier Sala-i-Martín. 1995. Economic growth. New York: McGraw-Hill.

Braudel, Fernand. 1972. The Mediterranean and the Mediterranean world in the age of Philip II. New York: Harper \& Row.

—. 1981-1984. Civilization and capitalism, fifteenth-eighteenth century. London: Collins.

Britannica Online. 1998. Retrieved from the World Wide Web: http://www.eb.com

Caldwell, John. 1982. Theory of fertility decline. London: Academic Press.

Central Intelligence Agency. (CIA). 1996. The world factbook. Washington, DC: Central Intelligence Agency.

1997. The world factbook. Retrieved from the World Wide Web: http://www.odci.gov/cia/ publications/factbook/index.html

Crosby, Alfred W. 1986. Ecological imperialism: The biological expansion of Europe, 900-1900. Cambridge, UK: Cambridge University Press.

Curtin, Philip D. 1989. Death by migration: Europe's encounter with the tropical world in the nineteenth century. Cambridge, UK: Cambridge University Press.

Diamond, Jared. 1997. Guns, germs, and steel: The fates of human societies. New York: Norton.

Encyclopedia Encarta. 1998. Retrieved from the World Wide Web: http://encarta.msn.com

Environmental Systems Research Institute. (ESRI). 1992. ArcWorld user's guide and data reference. Redlands, CA: Environmental Systems Research Institute.

. 1996a. ArcAtlas: Our earth. Redlands, CA: Environmental Systems Research Institute.

. 1996b. ArcWorld supplement data reference and user's guide. Redlands, CA: Environmental Systems Research Institute.

Food and Agriculture Organization. (FAO). 1995. The digital soils map of the world, version 3.5: Notes. [CD-ROM]. Rome: Food and Agriculture Organization.

Gallup, John Luke. 1998. Agricultural productivity and geography. Cambridge, MA: Harvard Institute for International Development. Retrieved from the World Wide Web: http://www.hiid.harvard. edu/pub/other/geodev.html

Grossman, G. M., and E. Helpman. 1991. Innovation and growth in the global economy. Cambridge, MA: MIT Press. 
Hall, Robert E., and Charles I. Jones. 1996. The productivity of nations. National Bureau of Economic Research working paper 5812, Cambridge, MA.

Jones, E. L. 1981. The European miracle: Environments, economies, and geopolitics in the history of Europe and Asia. Cambridge, MA: Cambridge University Press.

Kamarck, Andrew. 1976. The tropics and economic development: A provocative inquiry into the poverty of nations. Baltimore: Johns Hopkins University Press.

Knack, Stephen, and Philip Keefer. 1995. Institutions and economic performance: Cross-country tests using alternative institutional measures. Economics and Politics 7(3): 207-27.

Kornai, János. 1992. The socialist system: The political economy of communism. Princeton, NJ: Princeton University Press.

Krugman, Paul, and Anthony J. Venables. 1995. Globalization and the wealth of nations. Quarterly Journal of Economics 110(4): 857-80.

Landes, David S. 1998. The wealth and poverty of nations: Why some are so rich and some so poor. New York: Norton.

Lee, Douglas. 1957. Climate and economic development in the tropics. New York: Harper for the Council on Foreign Relations.

Leemans, Rik. 1990. Possible changes in natural vegetation patterns due to a global warming. Working paper WP-90-08, IIASA, Laxenburg, Austria. Geographic information system database; retrieved from the World Wide Web: http://www.grid.unep.ch/matgnv3.html

Maddison, Angus. 1995. Monitoring the world economy, 1820-1992. Paris: Organization for Economic Cooperation and Development.

McEvedy, Colin, and Richard Jones. 1978. Atlas of world population history. New York: Penguin.

McNeill, William Hardy. 1963. The rise of the West: A history of the human community. Chicago: University of Chicago Press.

. 1974. The shape of European history. Oxford, UK: Oxford University Press.

Murray, Christopher J. L., and Alan D. Lopez, eds. 1996. The global burden of disease. Cambridge, MA: Harvard University Press.

National Geographic Society. (NGS). 1995. The world: Political (map). Washington, DC: National Geographic Society.

National Oceanic and Atmospheric Administration. (NOAA). 1988. Data announcement 88-MGG-02, digital relief of the surface of the earth. Boulder, CO: National Geophysical Data Center. Geographic information system database; retrieved from the World Wide Web: http://grid2.cr.usgs. gov/dem/

Radelet, Steven C., and Jeffrey D. Sachs. 1998. Shipping costs, manufactured exports, and economic growth. Cambridge, MA: Harvard Institute for International Development. Retrieved from the World Wide Web: http://www.hiid.harvard.edu/pub/other/geodev.html

Rand McNally and Co. 1980. Rand McNally encyclopedia of world rivers. Chicago: Rand McNally.

Romer, Paul M. 1986. Increasing returns and long-run growth. Journal of Political Economy 94 (5): 1002-37.

1990. Endogenous technological change. Journal of Political Economy 98 (5, part 2): 71-102.

Sachs, Jeffrey D., and Andrew M. Warner. 1995a. Economic reform and the process of global integration. Brookings Papers on Economic Activity 1 (August): 1-118.

.1995b. Natural resource abundance and economic growth. HIID discussion paper 517a, Harvard Institute for International Development, Cambridge, MA.

Sellers, P. J., B. W. Meeson, J. Closs, J. Collatz, F. Corprew, D. Dazlich, F. G. Hall, Y. Kerr, R. Koster, S. Los, K. Mitchell, J. McManus, D. Myers, K.-J. Sun, and P. Try. 1997. An overview of the ISLSCP Initiative I global data sets. Retrieved from the World Wide Web: http://eosdata.gsfc.nasa.gov/ CAMPAIGN_DOCS/ISLSC/OVERVIEW_DOCUMENTS/overview.html

Smith, Adam. 1976. An inquiry into the nature and causes of the wealth of nations. 2 vols. Edited by Edwin Canaan. Chicago: University of Chicago Press. 
Summers, Robert, and Alan Heston. 1994. The Penn world tables, Mark 5.6. Retrieved from the World Wide Web: http://www.nber.org/pwt56.html

Tobler, Waldo, Uwe Deichmann, Jon Gottsegen, and Kelly Maloy. 1995. The global demography project. Technical report TR-95-6, National Center for Geographic Information and Analysis, Santa Barbara, CA.

United Nations. 1996. World population prospects 1950-2050. Revised. New York: United Nations. World Bank. 1997. World development indicators 1997. [CD-ROM]. Washington, DC: World Bank. . 1998. World development indicators 1998. [CD-ROM]. Washington, DC: World Bank.

World Health Organization. (WHO). 1967. Malaria eradication in 1966. WHO Chronicle 21 (9): 373-88.

- 1992. World malaria situation in 1990, Part II. WHO Weekly Epidemiological Record 67 (23): $169-74$.

1997a. "International travel and health: Vaccination requirements and health advice-situation as on 1 January 1997." [Internet, WWW], ADDRESS: http://mentor.who.ch/yellow/welcome.htm.

. 1997b. World malaria situation in 1994, Part I. WHO Weekly Epidemiological Record 36: 269-74.

World Resources Institute. (WRI). 1996. World resources database 1996-97. Washington, DC: World Resources Institute.

World Trade Organization. (WTO). 1995. International trade: Trends and statistics. Geneva, Switzerland: World Trade Organization. 


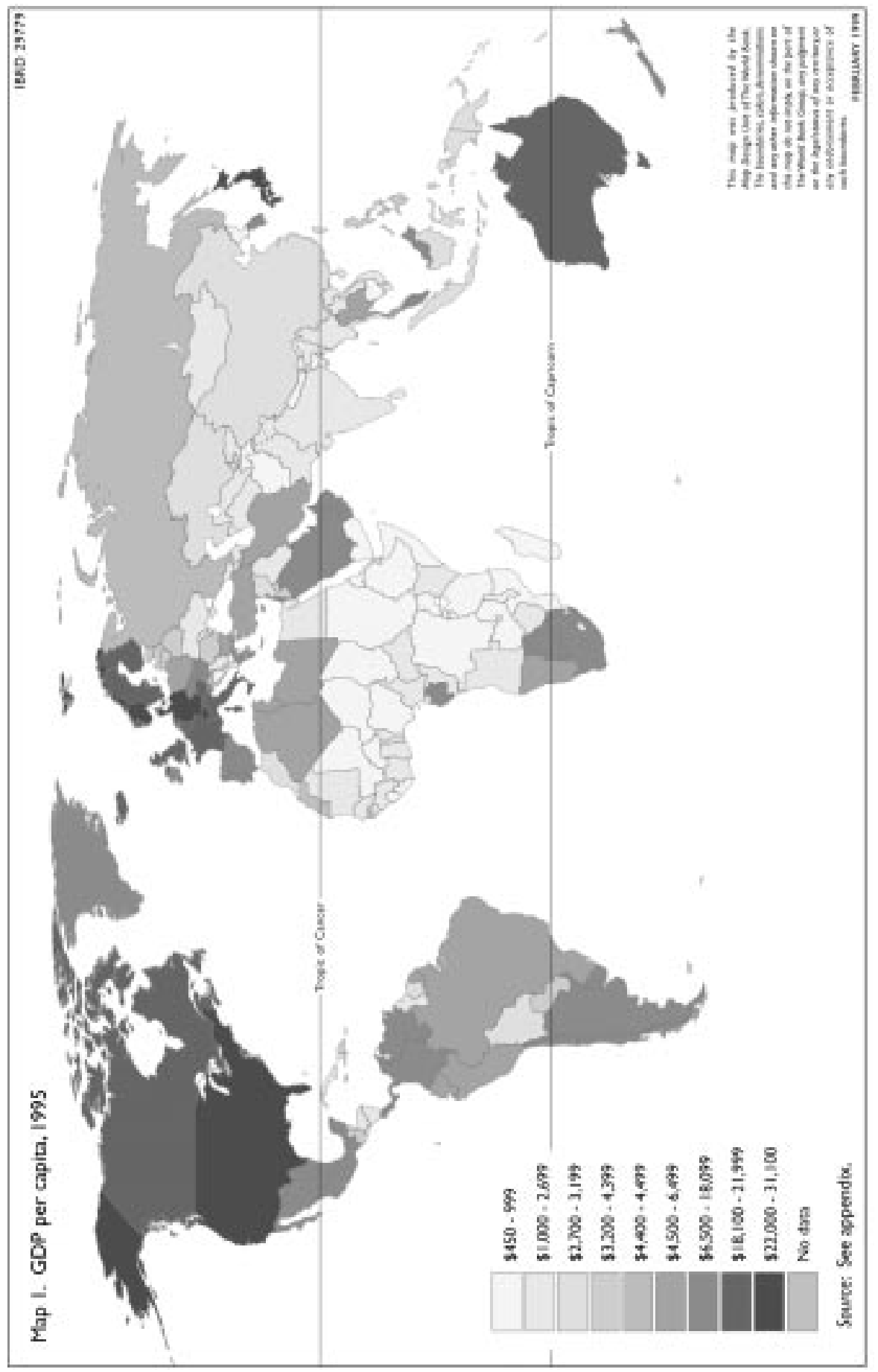




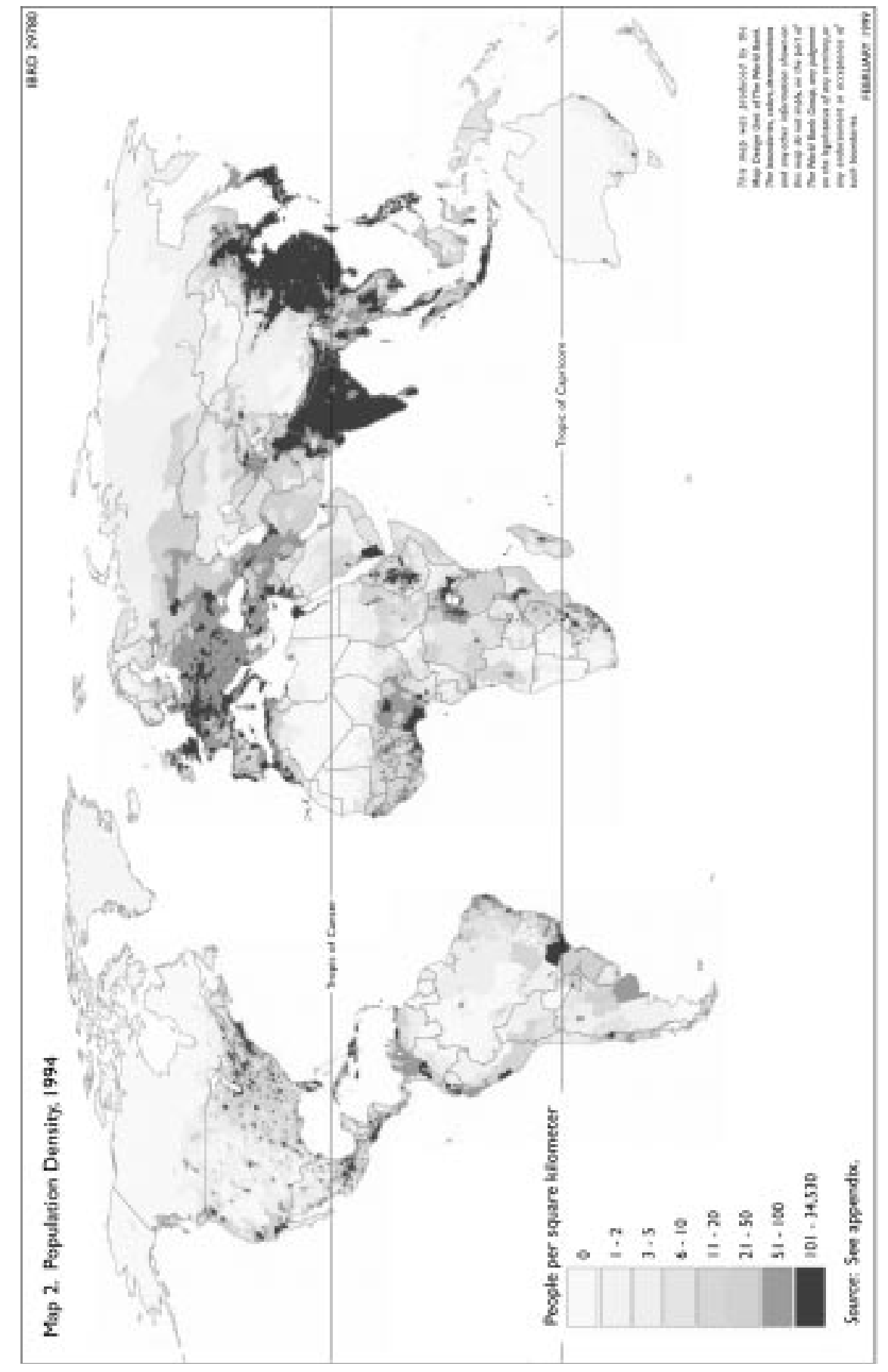




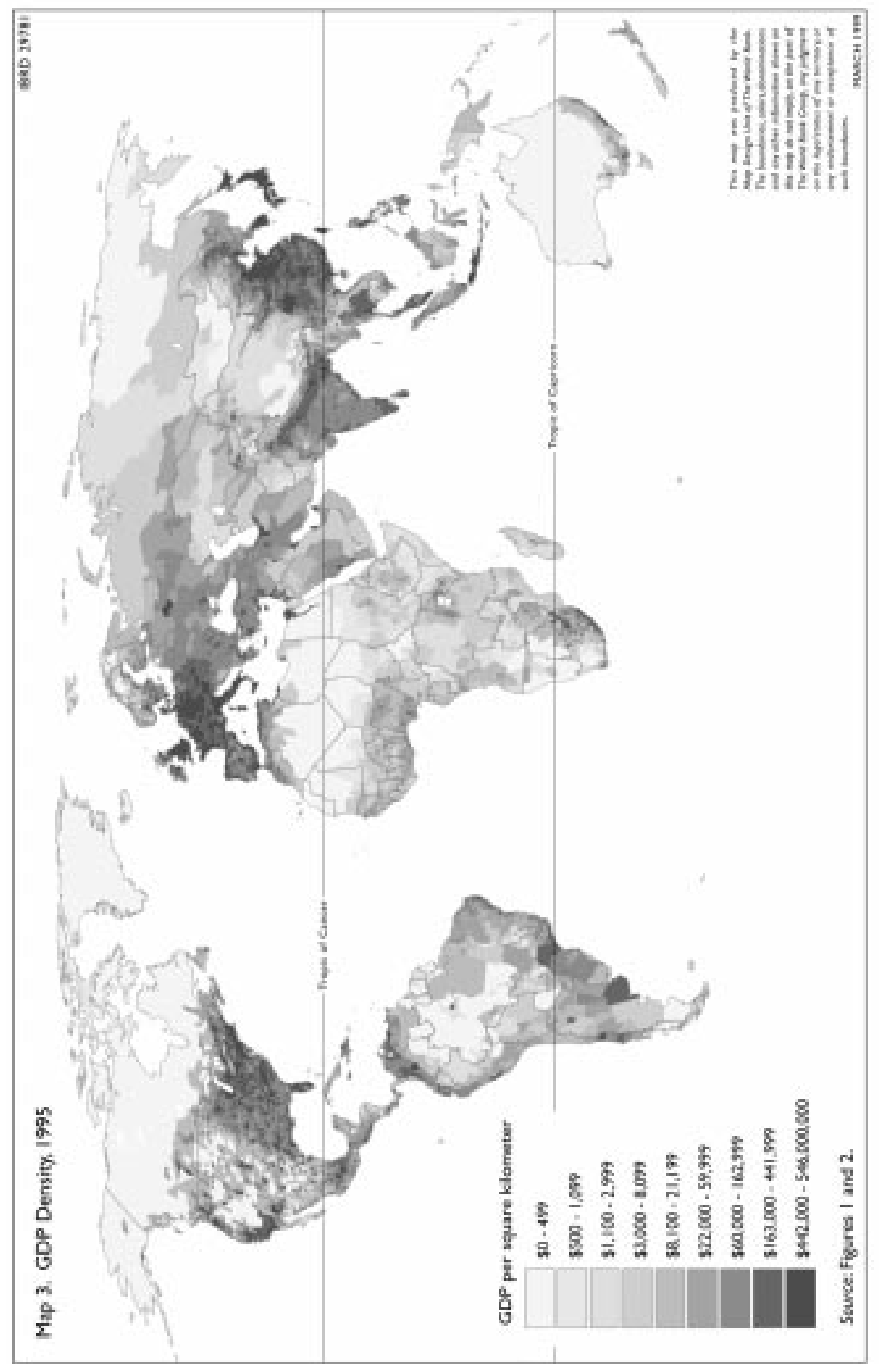




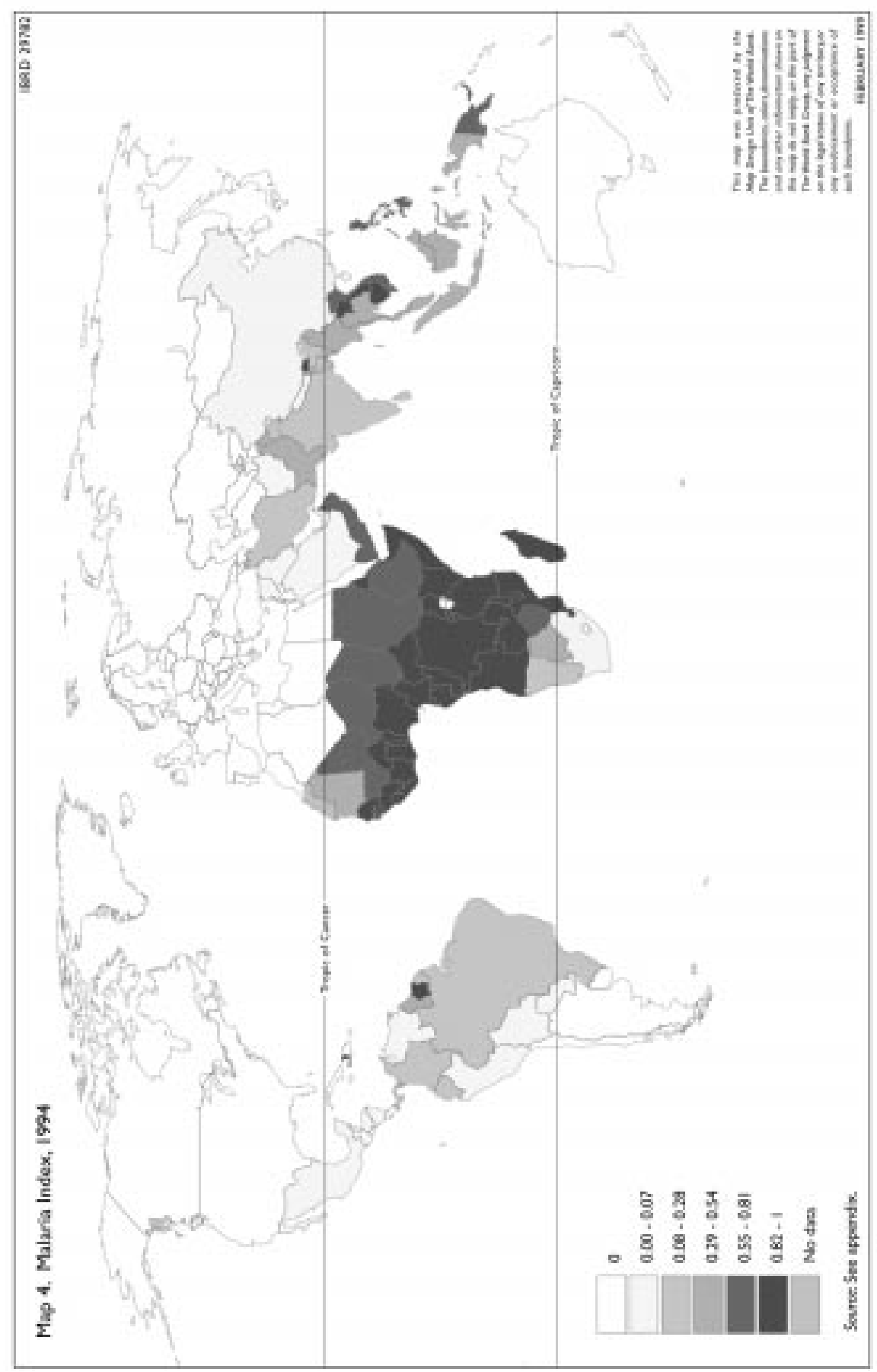




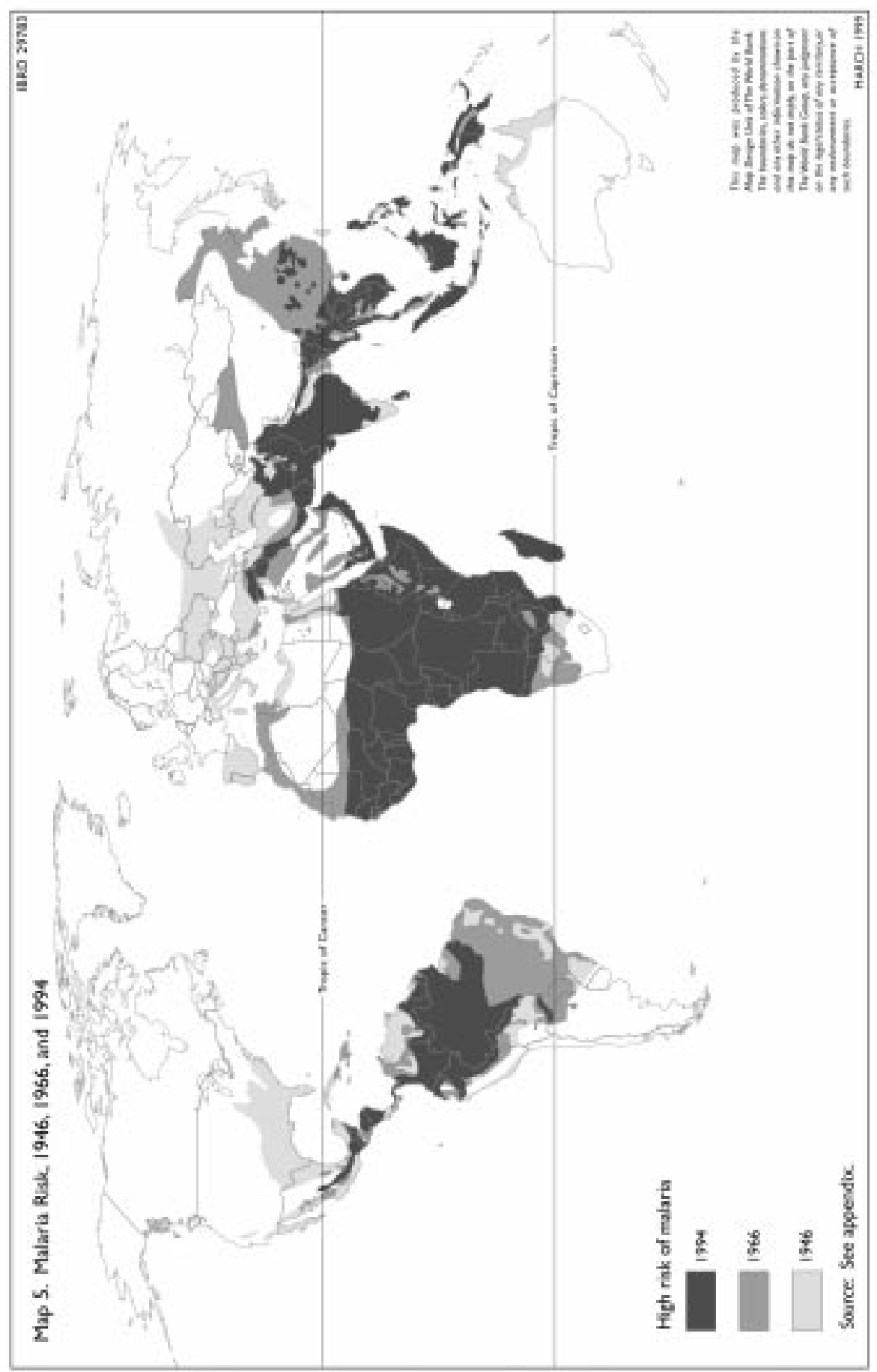




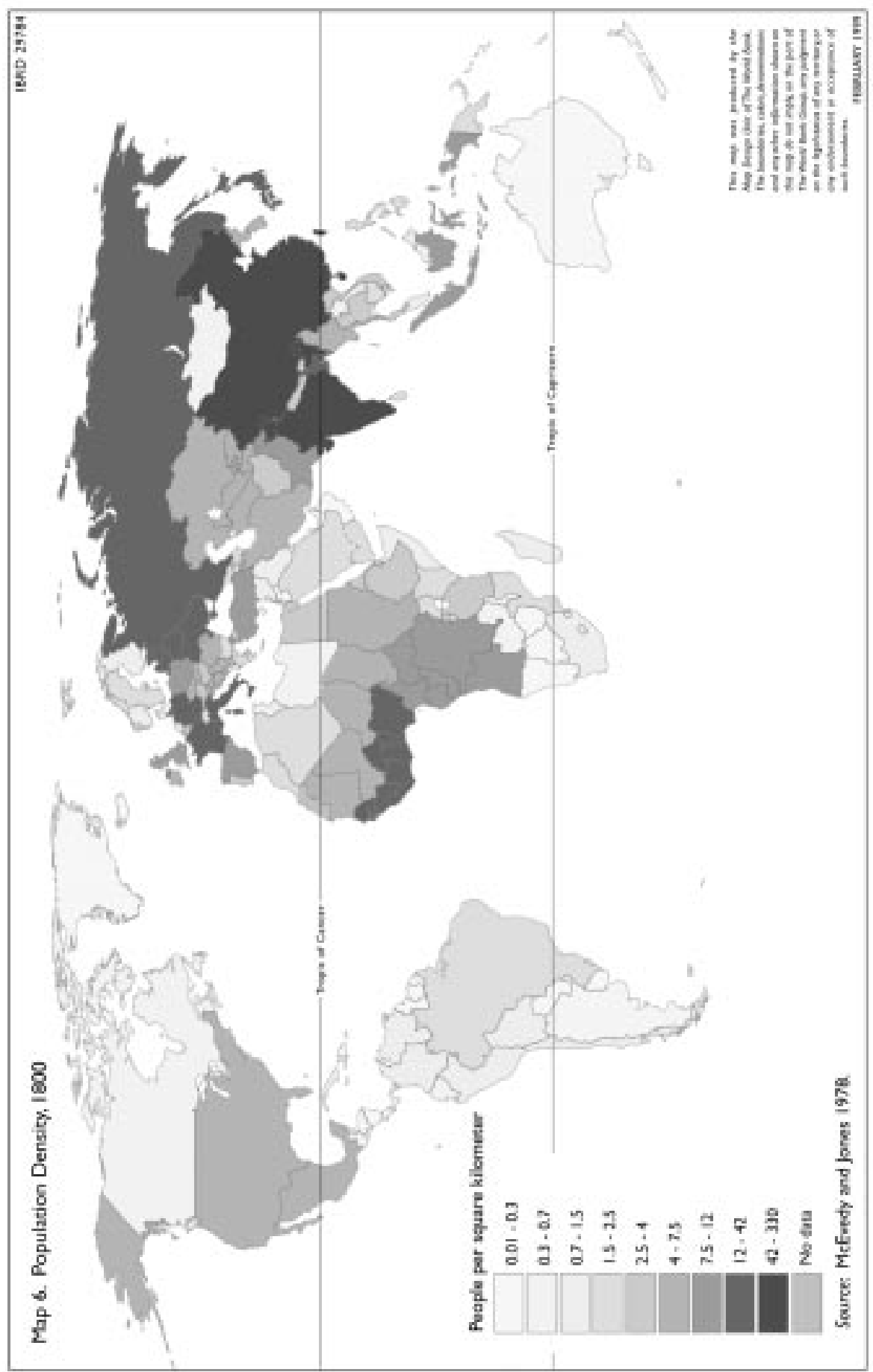




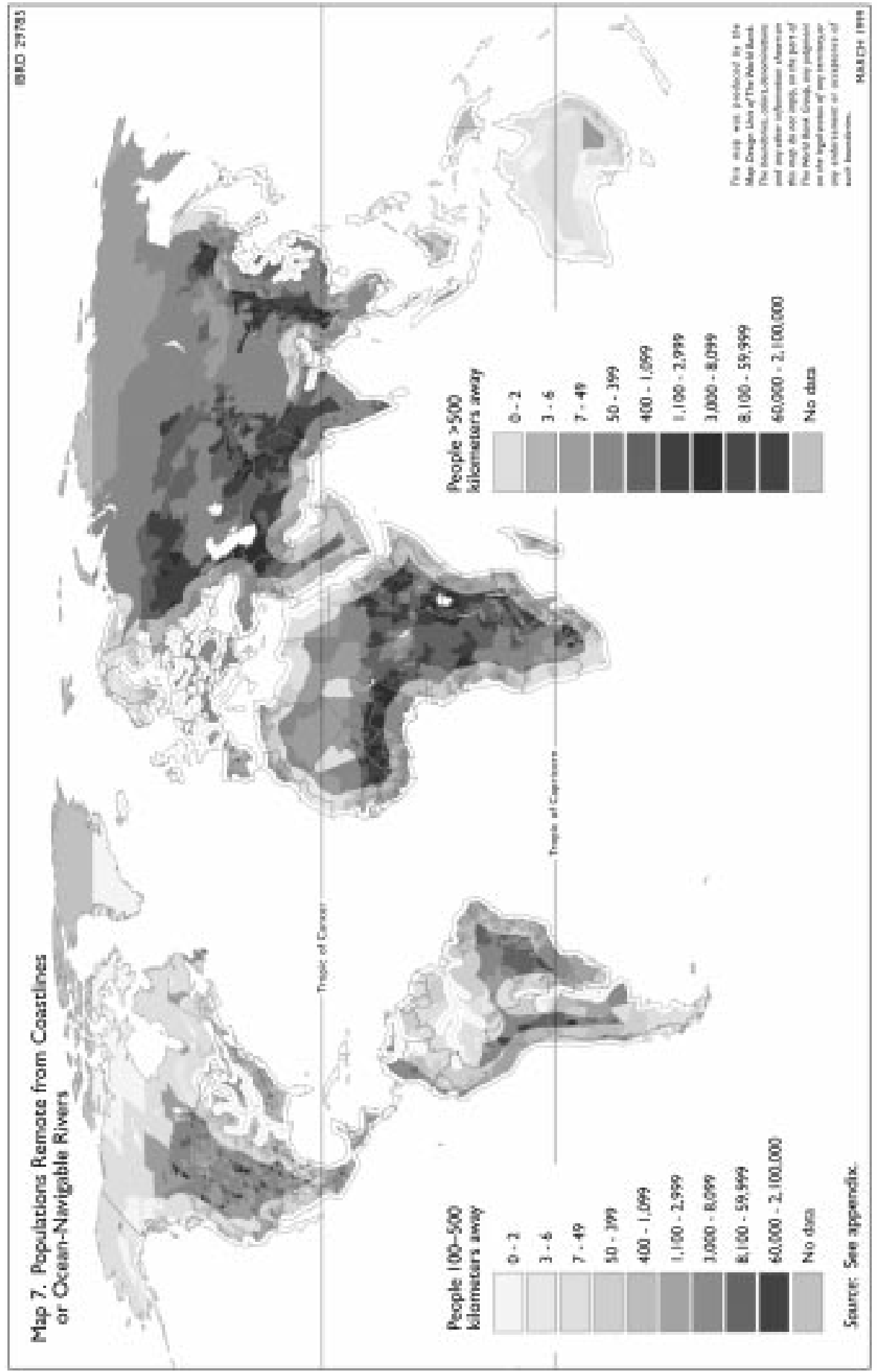




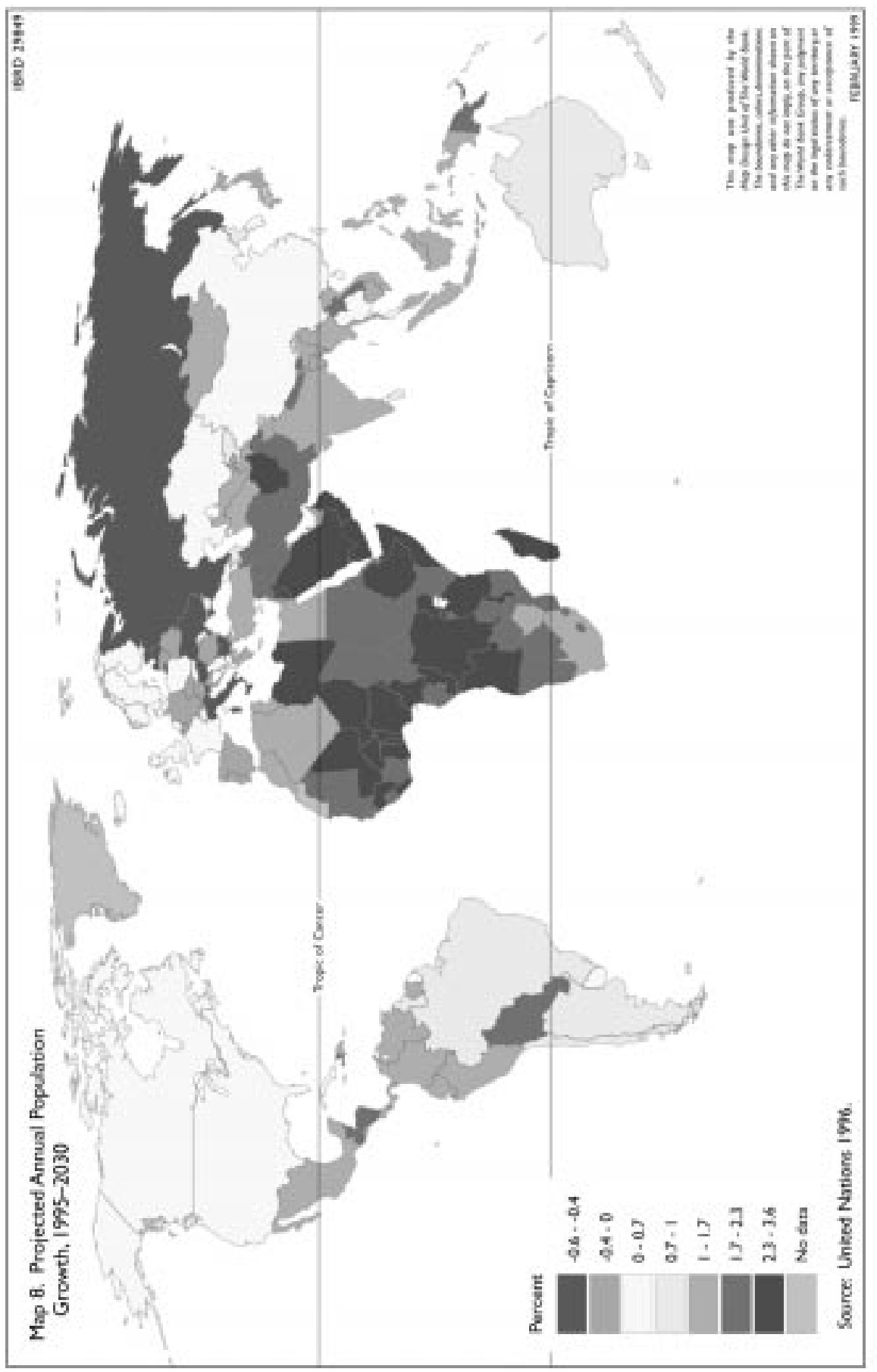


This page is NOT in the publication.

When it prints, throw it away. 
This page is NOT in the publication.

When the chapter prints, throw it away. 